\title{
New data on the age of the sedimentary infill of the Orava-Nowy Targ Basin - a case study of the Bystry Stream succession (Middle/Upper Miocene, Western Carpathians)
}

\author{
Anna WYSOCKA ${ }^{1, *}$, Maciej ŁOZIŃSKI ${ }^{1}$, Michał ŚMIGIELSKI ${ }^{1}$, \\ Urszula CZARNIECKA ${ }^{2}$ and Maciej BOJANOWSKI ${ }^{3}$
}

\author{
1 University of Warsaw, Faculty of Geology, wirki i Wigury 93, 02-089 Warszawa, Poland \\ 2 University of Oslo, Department of Geosciences, Sem Sælands vei 1, 0371 Oslo, Norway \\ 3 Institute of Geological Sciences, Polish Academy of Sciences, Twarda 51/55, 00-818 Warszawa, Poland
}

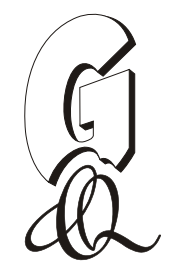

\begin{abstract}
Wysocka, A., Łoziński, M., Śmigielski, M., Czarniecka, U., Bojanowski, M., 2018. New data on the age of the sedimentary infill of the Orava-Nowy Targ Basin - a case study of the Bystry Stream succession (Middle/Upper Miocene, Western Carpathians). Geological Quarterly, 62 (2): 327-343, doi: 10.7306/gq.1408

The Neogene sedimentary succession of the Orava-Nowy Targ Basin directly overlies the Central Carpathian Paleogene Basin deposits, the Magura Unit, and the Pieniny Klippen Belt. It provides an excellent geological record that postdates the main Mesoalpine structural and geomorphological processes in the Western Carpathians. Sedimentological, petrographical and geochronological investigations have allowed for the re-examination of pyroclastic material, zircon dating, and a discussion on the relation of the Orava-Nowy Targ Basin to the exhumation of the Tatra Massif. The Bystry Stream succession is composed of NNW-inclined freshwater siltstones, sandstones and conglomerates. A few small, sometimes discontinuous, light grey intercalations of pyroclastic deposits and a single 1-2 $\mathrm{m}$ thick tuffite layer occur in the upper part of the succession. The tuffite contains an admixture of organic matter and siliciclastic grains (e.g., mica), suggesting that the volcanic ash fall was accompanied by normal deposition from weak currents. Sedimentation of deposits of the Bystry Stream succession took place in terrestrial settings, predominantly on floodplains and in rivers, in the vicinity of a hilly area supplying the basin with eroded material. The age of the tuffite layer from the Bystry Stream succession was determined at $11.87+0.12 /-0.24 \mathrm{Ma}$. The source of volcanogenic material in the tuffite was probably volcanic activity in the Inner Carpathians-Pannonian region, where effusive and volcanoclastic silica-rich rocks were being produced by extrusive and explosive activity $\sim 12 \mathrm{Ma}$. Obtained result connects the development of the Orava-Nowy Targ Basin at $\sim 12$ Ma with the late stage of the main episode of the Tatra Massif exhumation between 22-10 Ma.
\end{abstract}

Key words: tuffite, terrestrial facies, U-Pb geochronology, strike-slip faulting, Miocene, Orava-Nowy Targ Basin.

\section{INTRODUCTION}

The Orava-Nowy Targ (O-NT) Basin (Fig. 1) is filled mostly with terrestrial and freshwater sediments. The age of the onset of sedimentation in the O-NT Basin has been referred to the Badenian (Oszast and Stuchlik, 1977), Late Badenian or Sarmatian (Cieszkowski, 1995), or simply Sarmatian (Wieser, 1985; Nagy et al., 1996). The reliability of these estimations is insufficient and the exact age of the basin infill is still poorly constrained. The O-NT Basin provides an excellent geological record that postdates the main Mesoalpine structural and geomorphological processes (Golonka et al., 2005; Golonka and Picha, 2006) in the Western Carpathians. Consequently, a precise age determination is crucial for regional interpretations.

* Corresponding author, e-mail: anna.wysocka@uw.edu.pl Received: July 28, 2017; accepted: January 17, 2018; first published online: May 8, 2018
A few pyroclastic layers were identified both in outcrops and boreholes within the O-NT Basin. The most prominent of these occurrences is an outcrop of a 1-2 m thick tuffite layer in the Bystry Stream area. This tuffite layer was used by Wieser (1985) to determine the time of volcanic eruption and pyroclastic sedimentation. The age was determined at $8.7 \pm 0.6 \mathrm{Ma}$ based on zircons. However, the paper gave only scanty information about the applied dating method. It was later supplemented by Worobiec (1994) with the information that the result presented by Wieser (1985) was obtained by "Charles Naeser of the U.S. Geological Survey in Denver using the uranium-track method".

A series of floods between 2009 and 2010 in the Bystry Stream area uncovered the O-NT sedimentary succession that was poorly accessible for most of the 1990s and 2000s. This provided an excellent opportunity to study in detail the exposed sediments of the O-NT Basin in that region and compare them to the sedimentary sequence of the main part of the O-NT Ba$\sin$. It also enabled the re-examination of pyroclastic material and dating of zircons using the modern technique of laser ablation-multicollector-inductively coupled plasma-mass spectrometry (LA-MC-ICPMS). The results of these investigations are presented in this paper. 


\section{GEOLOGICAL SETTING}

The O-NT Basin is located in the Western Carpathians at the border between Slovakia and Poland. The O-NT sediments unconformably overlie the Mesoalpine consolidated basement comprising the Central Carpathian Paleogene Basin (CCPB) and the Pieniny Klippen Belt (PKB) in the south, and the Magura Nappe in the north (Fig. 1B). The O-NT Basin formed above these three units as a tectonically induced depression (Roth et al., 1963; Watycha, 1977; Bac-Moszaszwili, 1993; Baumgart-Kotarba, 1996, 2001; Pomianowski, 2003; Baumgart-Kotarba et al., 2004; Struska, 2008; Tokarski et al., 2012, 2016) across the boundary between the Inner and Outer Carpathians. Most authors interpreted this structure as a result of the Oligocene-Miocene activity of a regional-scale strike-slip fault zone (Kováč and Hók, 1993; Kováč et al., 1998). Possible movement could have taken place along the PKB (Pomianowski, 2003) or the Orava Fault (Jankj et al., 1984; Pospíšil, 1990; Bac-Moszaszwili, 1993; Baumgart-Kotarba, 1996, 2001; Baumgart-Kotarba et al., 2004). Such tectonic position of the O-NT Basin makes it an excellent geological marker that postdates the late deformation stages of the Western Carpathians.
Deformation of the CCPB occurred after the sedimentation of the youngest preserved sediments of Late Oligocene/Early Miocene age (Ostrysz beds, NN1 zone; Garecka, 2005). Existing studies show that an important part of the CCPB succession might have been eroded; therefore this estimation may not be very accurate (Anczkiewicz et al., 2005, 2013; Środoń et al., 2006). The last deformation stages of the southernmost parts of the Magura Nappe are dated by the occurrence of Lower Miocene sediments that are involved in the nappe formation (up to 23-18? Ma; Cieszkowski, 1992; Oszczypko et al., 2005; Kaczmarek et al., 2016). However, these estimations alone cannot be used to date the tectonic processes in the area without the support of precise dating of the O-NT Basin infill.

The O-NT Basin is a W-E-trending structure, $60 \mathrm{~km}$ long and $14 \mathrm{~km}$ wide (Figs. 1 and 2). The basin can be subdivided into two main parts: the Orava Basin (western) and the Nowy Targ Basin (eastern) (Fig. 2A). The Orava Basin is a rhomboidal structure filled with $\sim 1300 \mathrm{~m}$ of terrestrial and freshwater sediments, whereas the Nowy Targ Basin is a narrow half-graben with deposits up to $100 \mathrm{~m}$ thick. The O-NT Basin underwent intensive sedimentary processes, in contrast to the surrounding areas, which underwent erosion and served as a

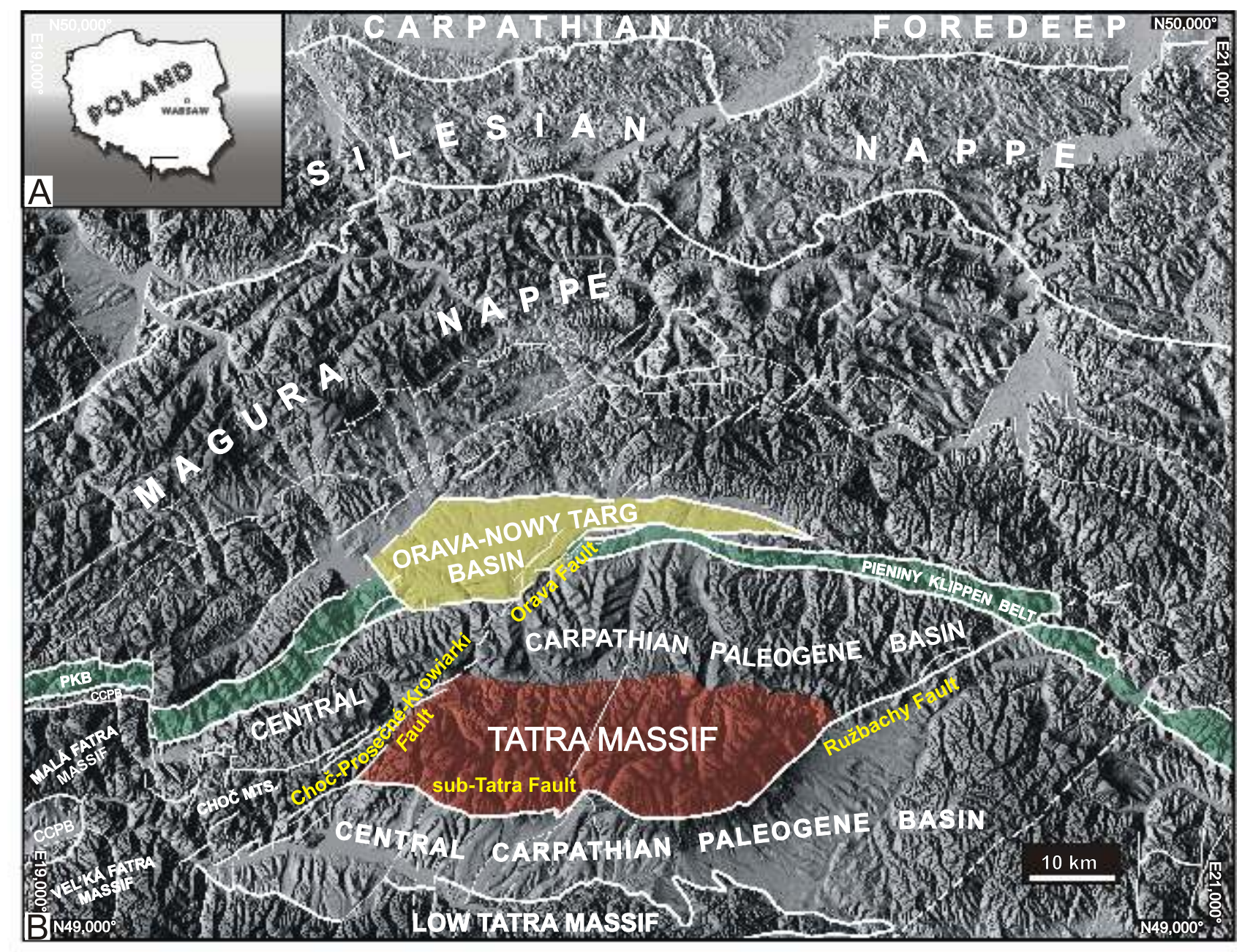

- major faults thrusts PKB - Pieniny Klippen Belt CCPB - Central Carpathian Paleogene Basin

Fig. 1. Sketch map of Poland, study area marked by box (A) and the Orava-Nowy Targ Basin against the background of adjacent units of the Western Carpathians; traces of selected map-scale faults and main thrusts are depicted (B) 


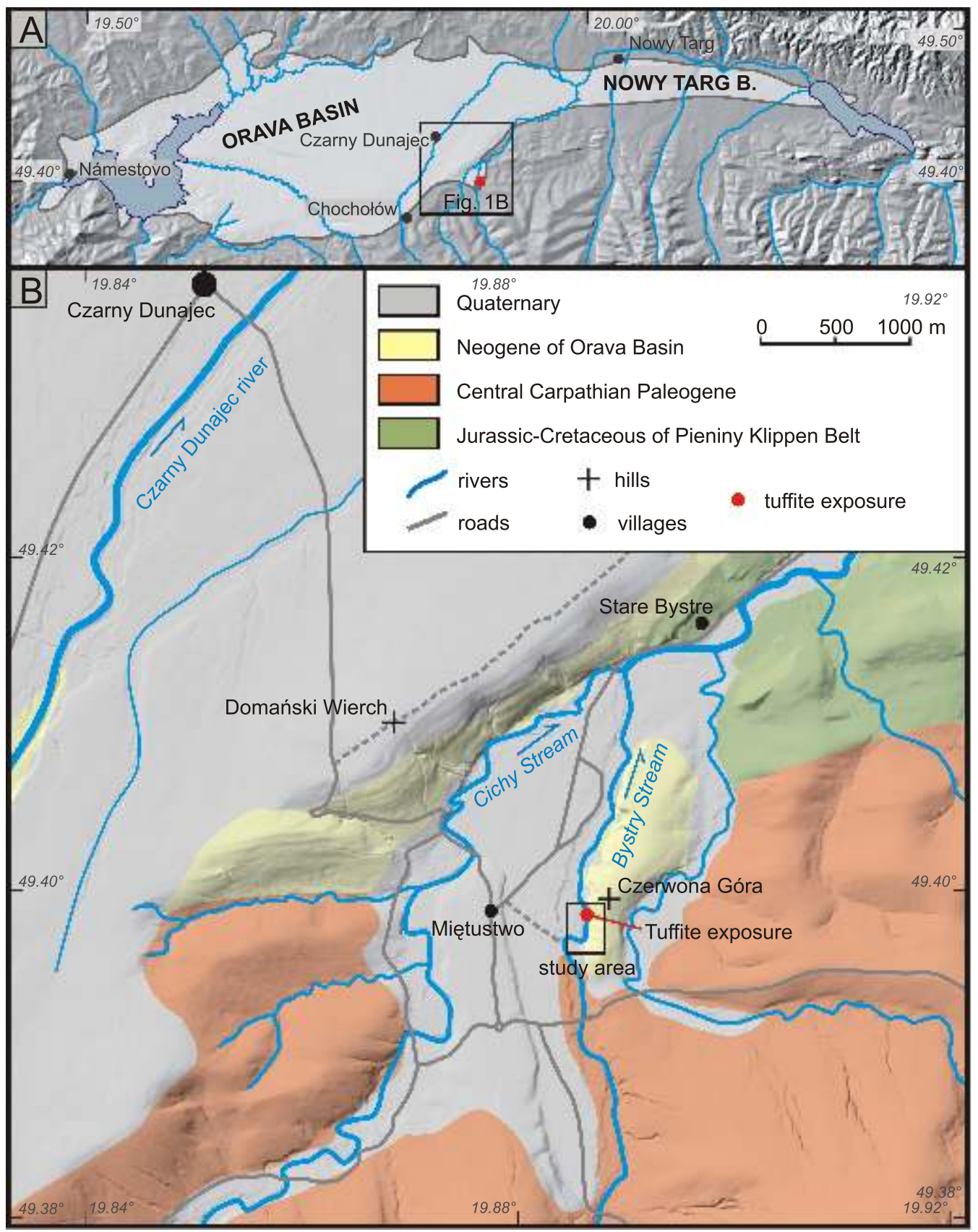

Fig. 2. General view of the Orava-Nowy Targ Basin subdived into the Orava and Nowy Targ basins (A) and geological sketch of the study area (B)

source area for the basin sediments. According to data from boreholes (Czarny Dunajec IG 1, Koniówka IG 1, and Domański Wierch D-1) and outcrops in the western part the basin, the infill consists predominantly of non- or weakly lithified fine-clastics (claystones, clayey siltstones and sandstones) deposited in river, swamp and lake settings. They are locally intercalated with conglomerates that often form alluvial fan sequences that are several metres thick (Birkenmajer, 1954, 1978; Watycha, 1976, 1977; Łoziński et al., 2015). Additionally, localized occurrences of lignites (Kołcon and Wagner, 1991; Nagy et al., 1996), tuffites (Beleš, 1974; Sikora and Wieser, 1974; Westwalewicz-Mogilska, 1974; Kołcon and Wagner, 1991) and freshwater limestones (Bojanowski et al., 2014; Łoziński et al., 2015) were observed.
The study area is located in the southeastern flank of the Orava Basin in the vicinity of Miętustwo and Stare Bystre villages (Fig. 2B). Isolated outcrops of Neogene deposits in this area (first noted by Raciborski, 1892) are located in the Bystry Stream bed and in the nearby scarp of the Czerwona Góra Hill (also known as the Srokowskie Bereki Hill). The Neogene sedimentary succession (Fig. 3) directly overlying the CCPB is composed of NNW-inclined freshwater siltstones, sandstones and conglomerates of presumed Sarmatian age (Birkenmajer, 1979). The conglomerates are dominated by clasts (up to $1.3 \mathrm{~m}$ ) derived from the CCPB. Limestones, radiolarites, and other exotic rocks derived probably from the PKB occur subordinately. A 1-2 m thick four-cycle tuff-tuffite layer (Sikora and Wieser, 1974; Fig. 4A) occurs at the base of the sev- 


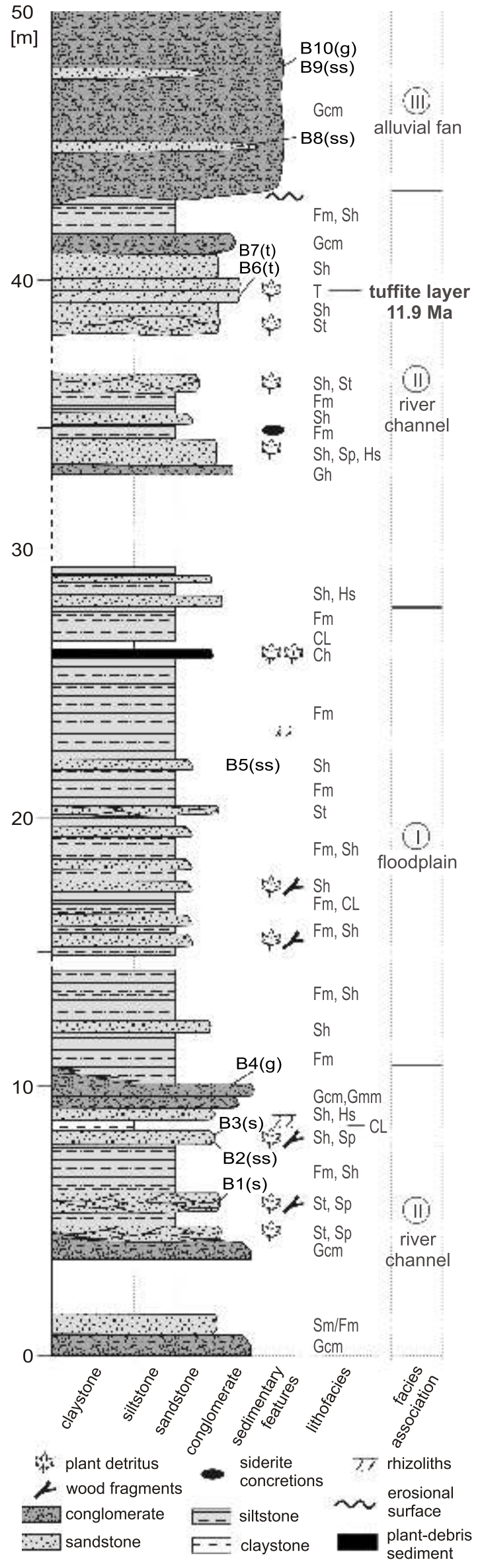

eral-metre-thick conglomerates. It contains vitroclasts, montmorillonite, crystaloclasts (quartz, sanidine, oligoclase, biotite) and accessory minerals (zircon, ilmenite, magnetite and lamprobolite). Detrital material was also reported and it is represented by mica and rounded zircon, garnet, rutile, tourmaline, allanite and well-preserved plant remnants (Sikora and Wieser, 1974; Worobiec, 1994).

The tuffite layer was investigated also by Westwalewicz-Mogilska (1974), who described sharp-edged fragments of volcanic glass, quartz, biotite and chlorite, as well as detrital quartz and concentrations of coaly matter. According to her, the mineral matrix of the rock is dominated by hydromica-type argillaceous minerals that originated from the weathering of volcanic ash and glass. Westwalewicz-Mogilska (1974) assumed a Late Pliocene or Plio-Pleistocene age (based on flora remnants; Oszast, 1970; Zastawniak, 1972) of the entire sedimentary sequence being part of the Domański Wierch alluvial fan.

\section{SAMPLES AND METHODS}

Standard sedimentological measurements were made along the Neogene succession cropping out in the Bystry Stream area (Figs. 2B and 3). Lithologic data coupled with observed sedimentary and diagenetic structures were used as the basis for the definition of lithofacies types. The observed lithofacies associations were interpreted in terms of sedimentary environments according to Miall $(2000,2006)$ and a previous study in the southern part of the Orava Basin (Łoziński et al., 2015).

Samples of diverse lithological types were collected from the Bystry Stream section for further examination. Sandstones and siltstones were subject to a quantitative petrographic analysis of six standard uncovered polished thin-sections prepared from siliciclastic and tuffite rocks collected in the outcrops. Thin-sections were studied using a NIKON Eclipse E600POL polarizing microscope (Nikon Corporation, Tokyo, Japan). Framework composition, matrix, cements and porosity were described using the point-counting method. Size and roundness of the framework components were also taken into account, along with types of contacts between the grains. Sorting of the framework components was determined by using comparison charts (Longiaru, 1987). Two thin-sections of tuffite were subsequently coated with carbon and examined using a Cameca SXFiveFE electron microprobe (EMP) equipped with 5 WDS spectrometers. Electron beam of $15 \mathrm{kV}$ acceleration voltage and $10 \mathrm{nA}$ current were used in taking back-scattered electron (BSE) images. WDS analyses were conducted in the same conditions, but with defocused beam (to $7 \mu \mathrm{m}$ ) to prevent the loss of light elements induced by electron beam. K $\alpha$ lines were measured for $F$ and $M g$ using LTAP; for $\mathrm{Na}, \mathrm{Al}$ and $\mathrm{Si}$ - TAP; for P, S, Cl, K, Ca, Ti - LPET; for Mn, $\mathrm{Fe}-$ LLIF crystals. L $\alpha$ lines of $\mathrm{Zr}$ and Ba were measured using LPET and LLIF crystals. Analyses were recalculated using the XPP matrix correction algorithm (Pouchou et al., 1990) and the following standards: $\mathrm{Ca}_{5} \mathrm{P}_{3} \mathrm{O}_{12} \mathrm{~F}$ for $\mathrm{F}$ and $\mathrm{P} ; \mathrm{Ca}_{5} \mathrm{P}_{3} \mathrm{O}_{12} \mathrm{Cl}$

Fig. 3. Tuffite position, lithofacies, and facies associations on a sedimentary log for the Bystry Stream succession

B1 to B10 sample number, denote gravel (g), sand (s), sandstone (ss) and tuffite (t); for lithofacies code explanations see Table 1 

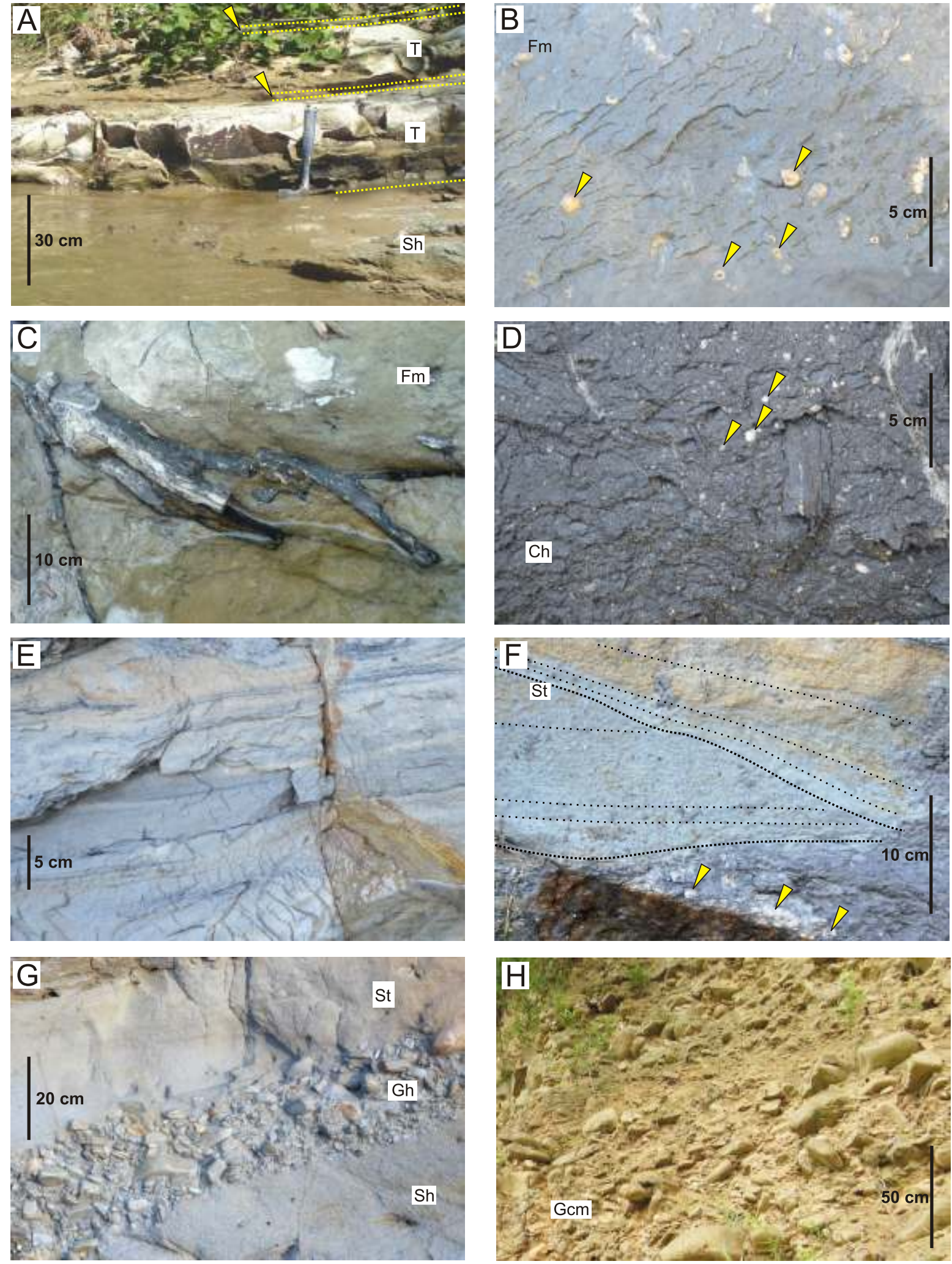

Fig. 4. Lithofacies and sedimentary structures typical for the Bystry Stream succession (lithofacies codes are given in boxes)

A - tuffite layers (from white and yellow to dark green) representing 2 cycles of deposition; each cycle ends with a $0.5-1 \mathrm{~cm}$ thick layer of very fine volcanic ash sediment (arrows); B - common massive siltstones with calcitic nodules and rhizocretions; C - a wood fragment preserved in massive siltstones; $\mathbf{D}-0.5 \mathrm{~m}$ thick unique layer of sediment extremely rich in plant detritus, wood fragments, as well as muddy intraclasts (arrows); E - horizontally laminated sandstones with frequent admixtures of plant detritus; $\mathbf{F}$ - layers of trough-bedded sandstones with corresponding erosion surfaces; the lowermost layer exhibits organic matter admixture and vegetation traces having a form of rhizocretions (arrows); $\mathbf{G}$ - sandstones intercalated by a 20-30 cm thick indistinctly bedded conglomerate layer; $\mathbf{H}$ - several-metres-thick disorganized conglomerates; for other explanations see Table 1 
for $\mathrm{Cl}$; albite for $\mathrm{Na}$ and $\mathrm{Si}$; orthoclase for $\mathrm{Al}, \mathrm{K}$; $\mathrm{MgO}$ for $\mathrm{Mg}$; diopside for $\mathrm{Ca}$; rhodonite for $\mathrm{Mn} ; \mathrm{Fe}_{2} \mathrm{O}_{3}$ for $\mathrm{Fe} ; \mathrm{SrBaNb}_{4} \mathrm{O}_{12}$ for $\mathrm{Ba}$; rutile for $\mathrm{Ti}$, and zircon for $\mathrm{Zr}$.

During fieldwork, sieve analysis of two gravel samples was made by using hand-made equipment composed of a specially prepared set of sieves. After the field sieve analysis, samples of the fine-grained part of the gravels and several samples of sands were collected and analysed in laboratory conditions. Based on the sieve analysis of four samples, the following parameters of grain-size distribution were counted: mean size $(\mathrm{Mz})$, standard deviation $(\delta)$ and skewness (Sk). Manual measurements of 300 individual clasts from the dominant grain-size classes (16-32, 32-64 and 64-128 mm) of each gravel sample allowed for describing their roundness and shape, based on the visual estimation after Powers (1953) and manual measurements after the methodology proposed by Zingg (1935). The lithology of all measured clasts was also described.

For $\mathrm{U}-\mathrm{Pb}$ analysis, a total of $2.5 \mathrm{~kg}$ of material was collected from the lower, middle and upper parts of the tuffite layer. Each sample was gently crushed, sieved, washed using a shaking table, and dried. Heavy mineral separates were prepared in magnetic and LST plus DIM heavy liquid separations, and submitted to the Arizona LaserChron Center for U-Pb laser analysis. The material from separates was incorporated into a 1" epoxy mount along with multiple fragments of the primary Sri Lanka (SL) zircon standard. The mounts were sanded down and polished, and CL imaging was used to pick random 50 crystals for age determination. Prior to the isotopic analysis, the mounts were cleaned in an ultrasound bath of $1 \%$ $\mathrm{HNO}_{3}$ and $1 \% \mathrm{HCL}$ in order to remove any residual common $\mathrm{Pb}$ from the mount surface.

$\mathrm{U}-\mathrm{Pb}$ geochronology of individual zircon crystals was conducted by laser ablation-multicollector-inductively coupled-mass spectrometry (LA-MC-ICPMS) (Gehrels et al., 2006, 2008). The isotopic analyses involved the ablation of zircon using a Photon Machines Analyte G2 excimer laser coupled with a $\mathrm{Nu}$ Instruments HR-MC-ICPMS. Helium carries the ablated material into the plasma source of the ICPMS, which is equipped with a flight tube of sufficient width for the simultaneous measurement of the $\mathrm{U}, \mathrm{Th}$, and $\mathrm{Pb}$ isotopes. The analyses were conducted with a $15 \mathrm{~mm}$ diameter laser spot using an acquisition routine consisting of one $12 \mathrm{~s}$ integration on peaks with the laser off (for backgrounds), twelve $1 \mathrm{~s}$ integrations with the laser firing, and a $30 \mathrm{~s}$ delay to ensure that the previous sample is purged from the collector block. Faraday detectors with $3 \times 1011 \Omega$ resistors measure ${ }^{238} \mathrm{U}$ and ${ }^{232} \mathrm{Th}$, and discrete dynode ion counters measure ${ }^{208-204} \mathrm{~Pb}$, all in a static mode. The drill rate was $\sim 1 \mathrm{~mm} / \mathrm{s}$, resulting in a final ablation pit depth of $\sim 12 \mathrm{~mm}$. The errors in determining the ${ }^{206} \mathrm{~Pb} /{ }^{238} \mathrm{U}$ and ${ }^{206} \mathrm{~Pb} /{ }^{204} \mathrm{~Pb}$ ratios result in a final measurement error of $\sim 1-2 \%$ (at 2-sigma level) in the ${ }^{206} \mathrm{~Pb} /{ }^{238} \mathrm{U}$ age for each analysis. The errors in determining the ${ }^{206} \mathrm{~Pb} /{ }^{207} \mathrm{~Pb}$ and ${ }^{206} \mathrm{~Pb} /{ }^{204} \mathrm{~Pb}$ ratios also result in $\sim 1-2 \%$ (at 2-sigma level) uncertainty in the age for grains that were older than $900 \mathrm{Ma}$; however, they were substantially larger for younger grains due to the low intensity of the ${ }^{207} \mathrm{~Pb}$ signal.

The common $\mathrm{Pb}$ correction was accomplished by using the $\mathrm{Hg}$-corrected ${ }^{204} \mathrm{~Pb}$ and assuming an initial $\mathrm{Pb}$ composition from Stacey and Kramers (1975). Uncertainties of 1.5 for ${ }^{206} \mathrm{~Pb} /{ }^{204} \mathrm{~Pb}$ and 0.3 for ${ }^{207} \mathrm{~Pb} /{ }^{204} \mathrm{~Pb}$ were applied to these compositional values based on the variation in the $\mathrm{Pb}$ isotopic composition in modern crystalline rocks. Interference of ${ }^{204} \mathrm{Hg}$ with ${ }^{204} \mathrm{~Pb}$ was accounted for the measurement of ${ }^{202} \mathrm{Hg}$ during laser ablation and subtraction of ${ }^{204} \mathrm{Hg}$ according to the natural ${ }^{202} \mathrm{Hg} /{ }^{204} \mathrm{Hg}$ of 4.35 .
The $U$ concentration and the $U / T h$ ratio were calibrated relative to the Sri Lanka zircon standard and were accurate to $\sim 20 \%$. The primary standard consisted of fragments of a single large zircon crystal with a well-calibrated ID-TIMS age of 563.5 $\pm 3.2 \mathrm{Ma}$ (2-sigma). In-run analyses of these fragments were conducted every ca. fourth measurement and the results were used to correct for the inter-element fractionation of $\mathrm{Pb} / \mathrm{U}$. For these particular analyses, the systematic uncertainty resulting from this calibration correction was $1.3 \%\left(2\right.$-sigma) ${ }^{206} \mathrm{~Pb} /{ }^{238} \mathrm{U}$ and $0.8 \%\left(2\right.$-sigma) ${ }^{206} \mathrm{~Pb} /{ }^{207} \mathrm{~Pb}$. $U$ and Th concentrations were calibrated relative to measurements of the SL, which contains $\sim 518 \mathrm{ppm} \mathrm{U}$ and $\sim 68 \mathrm{ppm}$ Th. The weighted mean, concordia plots and the TuffZirc diagram were prepared with Isoplot (Ludwig, 2008). A total of 62 age determinations for 50 individual crystals were performed.

\section{RESULTS}

\section{SEDIMENTOLOGY \\ OF THE BYSTRY STREAM SUCCESSION}

The studied sediments represent a range of terrestrial fine-clastic lithofacies (Table 1) recognized also in the previous sedimentological studies (Łoziński et al., 2015, 2017), and supplemented by coarse clastic lithofacies of different origin. The most common lithofacies Fm represents an apparently structureless siltstone, locally showing calcareous traces of roots (Fig. 4B) and enriched in plant detritus and wood fragments (Fig. 4C, D). The apparent massive structure may indicate rapid deposition or a post-depositional process which disturbed original sedimentary fabric. The bioturbation and wetting-drying cycles (Wetzel and Einsele, 1991) of fresh muds exposed after deposition have been already suggested as the processes which destroyed the original sedimentary structure of many O-NT sediments (e.g., Łoziński et al., 2017). This attributes lithofacies Fm to environments with episodic sedimentation, followed by periods of subaerial conditions allowing for plant vegetation and sediment weathering. The specific root-related features and stable isotopic composition of authigenic rhodochrosite and siderite in early diagenetic concretions, found in the Oravica River section, indicate that the sediments were water-logged and experienced oxygen-deficient conditions due to a water table rise shortly after deposition (Bojanowski et al., 2016).

Lithofacies Fm is accompanied by sandy (Fig. 4E, F) and subordinate pebbly (Fig. 4G) intercalations of lithofacies Sh, Sp, $\mathrm{St}$, and $\mathrm{Gh}$, deposited from channelized currents. They often contain plant detritus, as well as small wood fragments, and exhibit distinct laminations. The horizontally laminated sandstones Sh occur also as laterally extensive intercalations within lithofacies Fm and, in such a case, they might be deposited from sheet-flood weak traction currents. The coarse-grained, predominantly matrix-supported lithofacies $\mathrm{Gmm}$ represents a sediment of viscous sediment-gravity flow of presumably single depositional events. The several metre thick conglomerates of lithofacies $\mathrm{Gcm}$ (Fig. 4H) usually lack distinct bedding and imbrication. These large pebble and cobble bodies were probably deposited from either intensive sheet-flood flows with significant role of sediment-gravity force or non-cohesive clast-rich debris flows (Blair and McPherson, 1994).

A layer of lithofacies Ch predominantly consisting of plant debris and muddy clasts (Fig. 4D) appears as a special intercalation within the massive siltstones (Fm). Organic-rich sedimentation could have taken place in a local pond influenced by epi- 
Lithofacies distinguished in the Bystry Stream succession, with their key features and interpretation

\begin{tabular}{|c|c|c|c|}
\hline $\begin{array}{l}\text { Facies } \\
\text { code }\end{array}$ & Lithofacies & Description & Depositional mechanism \\
\hline Gmm & $\begin{array}{l}\text { matrix-supported, monomict, } \\
\text { disorganized conglomerates }\end{array}$ & $\begin{array}{l}\text { up to } 1 \mathrm{~m} \text { thick; composed of weathered clasts of flysch } \\
\text { sandstone and mudstone with a muddy matrix }\end{array}$ & cohesive, clay-rich debris flow \\
\hline Gcm & $\begin{array}{l}\text { clast-supported monomict } \\
\text { conglomerate }\end{array}$ & $\begin{array}{l}\text { up to } 5 \mathrm{~m} \text { thick; composed of flysch sandstone and mudstone } \\
\text { clasts, with admixture of quartzitic sandstones (up to } 2 \% \text { ), } \\
\text { cherts (up to } 2 \% \text { ), muddy intraclasts (up to } 5 \% \text { ); sandy or } \\
\text { muddy matrix; generally disorganized, very rare imbrications }\end{array}$ & $\begin{array}{l}\text { sheet-flood flow or } \\
\text { pseudoplastic debris flow }\end{array}$ \\
\hline Gh & $\begin{array}{l}\text { horizontally bedded } \\
\text { conglomerate }\end{array}$ & up to $0.5 \mathrm{~m}$ thick; composition of $\mathrm{Gcm}$; sandy matrix & bedload transport \\
\hline $\mathrm{Sp}, \mathrm{St}$ & $\begin{array}{l}\text { planar and trough } \\
\text { cross-bedded sandstone }\end{array}$ & $\begin{array}{c}\text { beds up to } 0.6 \text { m thick; fine- to coarse-grained, poorly-sorted, } \\
\text { polymict sandstone; plant detritus }\end{array}$ & 2D and 3D dune transport \\
\hline Sh & $\begin{array}{l}\text { horizontally laminated } \\
\text { sandstone }\end{array}$ & $\begin{array}{l}\text { beds up to } 0.3 \mathrm{~m} \text { thick; fine- to coarse-grained, poorly sorted, } \\
\text { polymict sandstone; very common plant detritus and wood } \\
\text { pieces; horizontal laminations with rare ripple-cross laminations }\end{array}$ & plane-bed transport \\
\hline Hs & $\begin{array}{l}\text { sandstone-dominated } \\
\text { heterolithic deposit }\end{array}$ & $\begin{array}{l}\text { beds up to } 0.5 \mathrm{~m} \text { thick; cyclically organized horizontally lami- } \\
\text { nated sandstones and siltstones; abundant plant detritus }\end{array}$ & $\begin{array}{l}\text { plane-bed transport alternated } \\
\text { by mud-suspension fallout }\end{array}$ \\
\hline $\mathrm{Fm}$ & massive siltstone & $\begin{array}{l}\text { beds up to } 2 \text { m thick; siltstone, sandy siltstone, and clayey } \\
\text { siltstone; generally massive, locally horizontal lamination; } \\
\text { grey-blue or red; common plant detritus; rare siderite concre- } \\
\text { tions, and pedogenic structures in places }\end{array}$ & $\begin{array}{l}\text { mud-suspension fallout influ- } \\
\text { enced by weak currents; occa- } \\
\text { sional pedogenic processes }\end{array}$ \\
\hline $\mathrm{CL}$ & claystone & beds up to $0.3 \mathrm{~cm}$; massive structure; grey or grey-blue & suspension fallout deposition \\
\hline $\mathrm{Ch}$ & $\begin{array}{c}\text { horizontally laminated plant } \\
\text { debris-rich sediment }\end{array}$ & $\begin{array}{c}\text { bed } 0.5 \mathrm{~m} \text { thick; abundant plant debris, subordinate muddy } \\
\text { clasts up to } 0.5 \mathrm{~cm}\end{array}$ & $\begin{array}{l}\text { episodic plane-bed transport } \\
\text { and suspension fallout }\end{array}$ \\
\hline $\mathrm{T}$ & tuffite & $\begin{array}{c}\sim 1-2 \mathrm{~m} \text { thick layer comprised of } 4-5 \text { cycles, as well as small } \\
1 \mathrm{~cm} \text { thick often fuzzy intercalations; white or yellow, } \\
\text { often green when wet }\end{array}$ & $\begin{array}{l}\text { volcanic ash fall influenced } \\
\text { by weak currents }\end{array}$ \\
\hline
\end{tabular}

Table 2

Facies associations and interpreted depositional environment

\begin{tabular}{|c|c|c|c|}
\hline Association & Dominant lithofacies & Minor lithofacies & Depositional environment \\
\hline I & $\mathrm{Fm}$ & $\mathrm{Sh}, \mathrm{Ch}, \mathrm{CL}, \mathrm{T}$ & floodplain \\
\hline II & Gcm, Sh, St & $\mathrm{Gmm}, \mathrm{Fm}$ & gravel- or sand-dominated fluvial channel, possibly distal alluvial fan \\
\hline III & $\mathrm{Gcm}$ & $\mathrm{Sh}, \mathrm{St}$ & gravel-dominated fluvial channel of proximal alluvial fan \\
\hline
\end{tabular}

sodic, quickly deceasing currents. The pyroclastic deposition occurred as both a few small, sometimes discontinuous, light grey intercalations and one 1-2 m thick tuffite layer (Fig. 4A). The latter was deposited in 4 to 5 cycles (Sikora and Wieser, 1974; Westwalewicz-Mogilska, 1974) separated by more clayey sedimentation. The tuffite contains an admixture of organic matter and siliciclastic grains (e.g., mica), suggesting that the volcanic ash fall was accompanied by normal deposition from weak currents.

The studied section is dominated by facies association (I) of massive siltstones (Fm) and subordinately horizontally-bedded sandstones (Sh) (Table 2). The discontinuous sedimentation of fine-clastic material very likely appeared on widespread floodplains during abundant clastic supply. Episodes of subaerial sediment exposure favoured plant development, root and fauna bioturbation, and sediment weathering. The oxygen-abundant conditions in the topmost layer of the sediment could have led to organic matter decay and resulted in selective preservation of plant remnants, whereas, deeper in the sediment column, oxygen could have been exhausted. Local ponds and depressions served as ephemeral channels during frequent floods and were filled with coarser siliciclastic material (Sh) or plant debris $(\mathrm{Ch})$.
The floodplains were cut by rivers represented by facies association (II) of horizontally- and trough cross-bedded sandstones and conglomerates (Sh, Sp, St, Gh, Gmm) (Table 2). A prominent shift in sedimentation is marked by deposition of thick conglomerates (Gcm) and subordinate sandstones (Sh, St), and subsequent vanishing of the fine-clastic lithofacies $\mathrm{Fm}$. This is interpreted as a manifestation of large alluvial fan deposition, pointing to the basin proximity to a hilly or mountainous area.

\section{GRAVELS}

The results of sieve analysis in gravels allowed counting the parameters of grain-size distribution, such as mean size (Mz) and standard deviation $(\delta)$. The mean size indicates that gravels from both B4(g) and B10 $(\mathrm{g})$ samples can be classified as fine-grained gravels (Mz: -5.16 and -5.29$)$. The standard deviation values ( $\delta: 1.38$ and 1.99$)$ point to poor sorting of the deposits. There are three main grain-size classes of the gravels: 16-32 mm, 32-64 mm, and 64-128 mm. The classes comprise $\sim 80 \%$ of all analysed samples. Gravel clasts from the main grain-size classes were studied according to their roundness 

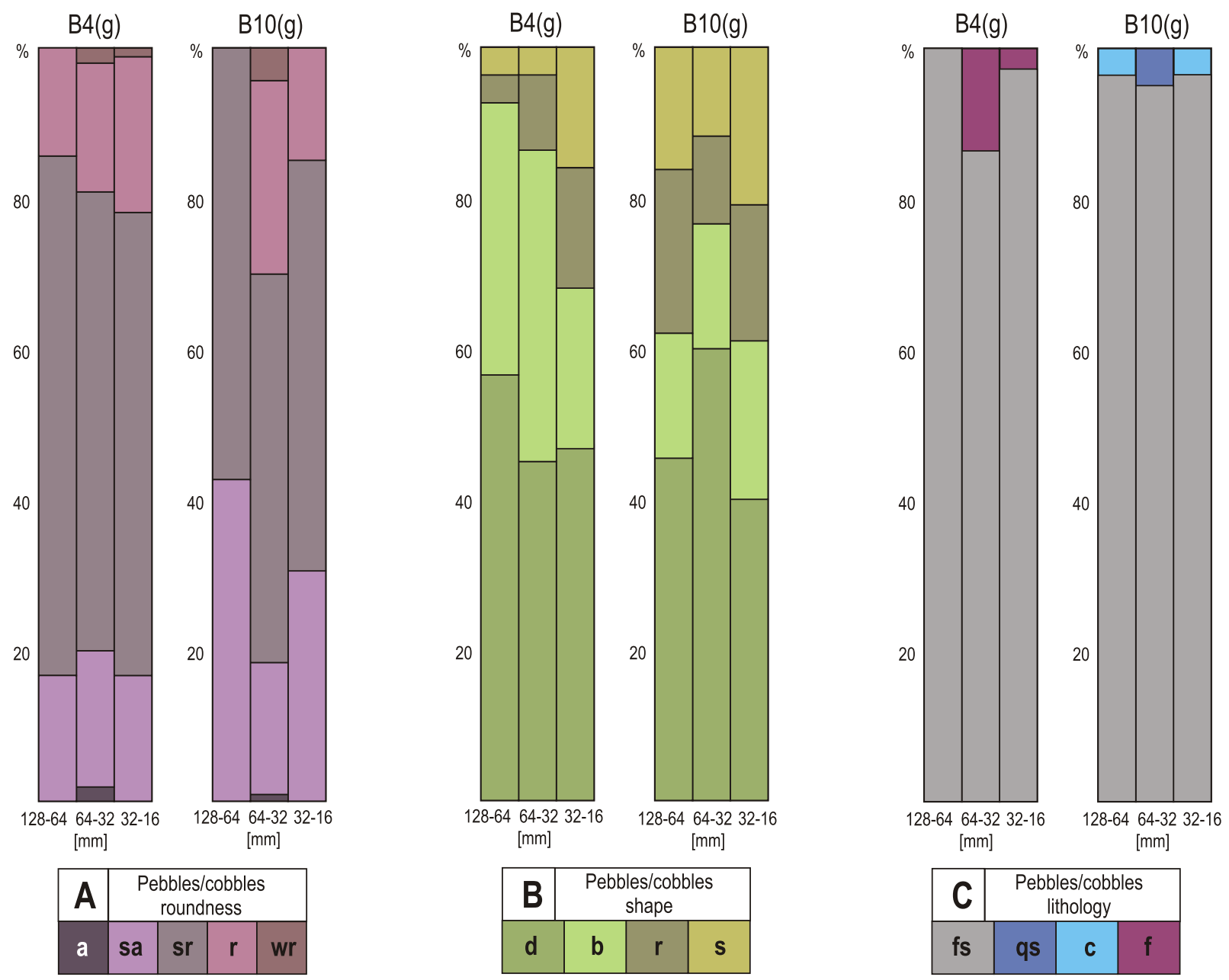

Fig. 5. Characteristics of gravels in the most frequent grain-size classes

A - roundness of clasts on the basis of grain images for estimating the roundness of sedimentary particles after Powers (1953): a - angular, sa - sub-angular, sr - sub-rounded, $r$ - rounded, wr - well-rounded; B - classification of shapes of gravel clasts on the basis of Zingg's diagram (1935): $d$ - disc, $b$ - bladed, $r$ - rod, $\mathbf{s}$ - sphere; C - quantitative analysis of gravel clast lithology: fs flysch sandstones and siltstones, qs - quartzitic sandstones, $c$ - cherts, $\mathrm{f}$ - claystones and silty claystones; sample location - see Figure 3

and shape (Fig. 5). The clasts are usually sub-rounded (Fig. $5 A)$. Sub-angular and rounded clasts are also common. Well-rounded and angular clasts were sparsely noted. Taking into account the shape, discoidal clasts predominate (Fig. 5B) in both samples. In the first sample B4(g), bladed clasts are also frequent, whereas the rod and sphere shapes are rarely present. In the second sample B10(g), similar quantities of bladed, rod and sphere shape types are noted.

The gravel clasts were studied also with regard to their lithology (Fig. 5C). Quantitative analysis allowed distinguishing four lithological types: flysch sandstones and siltstones, quartzitic sandstones, cherts, and claystones and silty claystones. Both samples are composed almost entirely of flysch sandstones and siltstones (Fig. 6A). The B4(g) sample contains a small proportion of claystones and silty claystones. Based on macroscopic observations during field study, the clasts are similar to the clayey and silty clayey material that is typical of the Neogene deposits occurring in the Bystry Stream succession and in other areas of the O-NT Basin. The B10 $(\mathrm{g})$ sample contains small amounts of quartzitic sandstones and cherts. The clasts have an extrabasinal origin.

\section{SANDS AND SANDSTONES}

Microscopic grain-size analysis of the studied deposits allowed distinguishing mudstones, siltstones and silty sandstones (classification according to Picard, 1971). Sandstones, classified by using a compilation of several petrographic classifications (McBride, 1963; Dott, 1964; Folk et al., 1970; Pettijohn et al., 1972; Williams et al., 1982), can be described as sublithic wacke (Fig. 6B, C), lithic feldswacke (Fig. 6B, D) and lithwacke (Fig. 6B, E, F).

Quartz and lithic clasts predominate among the framework components (Table 3 and Fig. 6B). Quartz is mostly monocrystalline, although polycrystalline grains are also present (Figs. 6C, D and 7A-C). The lithics are represented by fragments of crystalline rocks (Figs. 6C, E, F and 7F), as well as sedimentary rocks (siltstones, mudstones, mudshales, clayey clasts and limestones) (Figs. 6E, F and 7A, B). Feldspars were also noted (Table 3 and Fig. 6C, D). Micas are represented mostly by muscovite (Table 3 and Fig. 6C, D), but biotite is present as well. Heavy minerals, organic matter and opaque minerals were found only in trace amounts (Table 3). 



Fig. 6. Gravely and sandy lithofacies from the study area

A - examples of lithic clasts from the most common size classes; the lithics are dominated by sandstones and siltstones derived from the CCPB and the Magura Unit; B - petrographic classification of the studied sandstones (compiled and modified from: McBride, 1963; Dott, 1964; Folk et al., 1970; Pettijohn et al., 1972; Williams et al., 1982); the sandstones are composed of $>10 \%$ of matrix, therefore they are called wackes; C - poorly sorted sublithic wackes composed of quartz (Q), lithic clasts (e.g., crystalline rocks fragments - LTC), feldspars (F) and micas (Msc); D - poorly sorted lithic feldswackes (Q - quartz, F-feldspars, Msc muscovite); E, F - very poorly sorted lithwackes dominated by lithic clasts of sedimentary (LTs) and crystalline (LTC) rocks; intergranular porosity $(p)$ marked by blue epoxy is the most common in the sandstones; C, D, F-crossed polarized light, E-plane polarized light

The framework grains are generally sub-angular and angular, sparsely sub-rounded. Lack of contacts and point contacts between the grains were most commonly observed. Long and concavo-convex contacts were noted very rarely. The deposits are poorly and very poorly sorted.
The matrix consists of detrital grains and is widely present in the sandstones (Table 3). Diagenetic minerals such as clay minerals, carbonates, iron oxides and hydroxides were also found. The amount of pore spaces is variable and intergranular porosity predominates (Table 3 and Fig. 6E). 
Petrographic characteristics of the Neogene rocks occurring in the Bystry Stream succession

\begin{tabular}{|c|c|c|c|c|c|c|c|c|c|c|c|c|c|c|c|c|c|c|c|c|c|c|c|c|c|c|c|c|c|c|c|c|c|c|c|}
\hline \multirow{2}{*}{\multicolumn{2}{|c|}{ Sample }} & \multicolumn{23}{|c|}{ Framework components } & \multicolumn{6}{|c|}{ Matrix/cements } & \multicolumn{5}{|c|}{ Porosity } \\
\hline & & \multicolumn{7}{|c|}{ Quartz } & \multirow{3}{*}{ 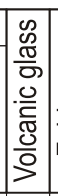 } & \multirow{3}{*}{$\begin{array}{l}\frac{\infty}{0} \\
\frac{0}{0} \\
\frac{0}{0} \\
\frac{0}{0} \\
\stackrel{1}{1}\end{array}$} & \multirow{3}{*}{ 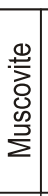 } & \multirow{3}{*}{ 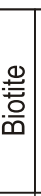 } & \multirow{3}{*}{ 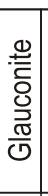 } & \multirow{3}{*}{ 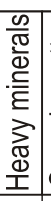 } & \multirow{3}{*}{ 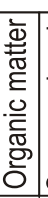 } & \multirow{3}{*}{ 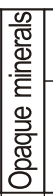 } & \multirow{2}{*}{\multicolumn{6}{|c|}{ Lithic clasts }} & \multirow{3}{*}{$\stackrel{*}{*}_{z}^{*}$} & \multirow{3}{*}{$\Sigma$} & \multirow{3}{*}{ 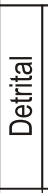 } & \multirow{3}{*}{ 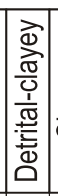 } & \multirow{3}{*}{\begin{tabular}{|l|} 
\\
$\frac{\partial}{0}$ \\
$\frac{\overrightarrow{0}}{0}$ \\
\end{tabular}} & \multirow{3}{*}{ 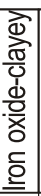 } & \multirow{3}{*}{ 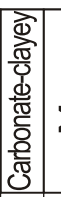 } & \multirow[b]{3}{*}{$\Sigma$} & \multirow{3}{*}{ 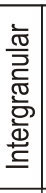 } & \multirow{3}{*}{ 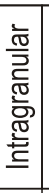 } & \multirow{3}{*}{ 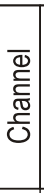 } & \multirow{3}{*}{$\stackrel{\circ}{>}$} & \\
\hline & & & Qm & & & $Q p$ & & & & & & & & & & & & & & & & & & & & & & & & & & & & & \\
\hline Signature & Lithology & 吝 & ᄅ્ & $\Sigma$ & ָூ & 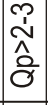 & $\Sigma$ & $\Sigma$ & & & & & & & & & $\stackrel{\mathbb{\widetilde { D }}}{\stackrel{\Xi}{\Xi}}$ & $\stackrel{\mathscr{\Xi}}{\Xi}$ & $\frac{\cup}{\vec{W}}$ & $\stackrel{\infty}{\Xi}$ & $\stackrel{\text { * }}{\text { 巨E }}$ & $\Sigma$ & & & & & & & & & & & & & $\Sigma$ \\
\hline B9(ss) & sandstone & 20.0 & 1.3 & 21.3 & 3.0 & 3.0 & 6.02 & 27.3 & & 2.7 & & & & & & & & 6.3 & 6.31 & 10.7 & 75.4 & 22.3 & 31.3 & 53.7 & 25.0 & 12.3 & 0.82 & 2.1 & & 40.3 & 5.8 & & & & 5.8 \\
\hline B8(ss) & sandstone & 6.3 & 1.0 & 7.3 & 2.7 & 3.7 & 6.4 & 13.7 & & 1.7 & 0.3 & & & & 3.7 & & 3.4 & 8.3 & 11.7 & 19.3 & 32.0 & 33.0 & & 52.3 & 9.3 & 13.0 & 1.51 & 10.36 & 6.04 & 40.0 & 5.0 & & 2.3 & 0.3 & 7.7 \\
\hline$B 7(t)$ & tuffite & & & & & & & 1.3 & 48.3 & & 1.0 & & & 3.0 & & & & & & 1.7 & 1.0 & 2.7 & 1.3 & 57.9 & 41.3 & & & & & 41.3 & 0.3 & 0.7 & & & 1.0 \\
\hline$B 6(t)$ & tuffite & & & & & & & 7.0 & 49.0 & 1.6 & 2.0 & & & 2.0 & & & & & 1.6 & 1.0 & 2.0 & 4.7 & 0.7 & 66.0 & 33.0 & & & & & 33.0 & 0.6 & & & & 0.6 \\
\hline $\mathrm{B} 5(\mathrm{ss})$ & sandstone & 25.7 & 2.0 & 27.7 & 4.0 & 0.3 & 4.3 & 32 & & 1.3 & 1.3 & 1.0 & 0.3 & 0.3 & 0.3 & 3.4 & 0.7 & 0.7 & 1.4 & & 2.3 & 3.7 & 0.7 & 44.3 & 15.0 & 40.3 & & 0.7 & & 55.7 & & & & & \\
\hline B2(ss) & sandstone & 25.7 & 4.0 & 29.7 & 4.7 & 1.3 & 6.03 & 35.7 & & 8.3 & 4.3 & 1.7 & & 0.7 & & & 1.3 & 0.7 & 2.0 & 0.7 & 3.7 & 6.3 & 4.7 & 61.7 & 7.0 & 25.0 & 0.80 & 0.8 & & 33.7 & 4.7 & & & & 4.7 \\
\hline
\end{tabular}

$\mathrm{Qm}$ - monocrystalline quartz with: Qmnu - non-undulatory extinction, Qmu - undulatory extinction, Qp - polycrystalline quartz, containing: Qp2-3 - 2 or 3 crystals per grain, Qp $>3$ - more than 3 crystals per grain; lithic clasts of: LTma - magmatic rocks, LTme - metamorphic rocks, LTc - total crystalline rocks fragments, LTs - sedimentary rocks; sample location - see Figure 3

The results of microscopic analysis, such as the presence of high amounts of matrix, small amounts of primary pore spaces, low degree of grain roundness, and poor or very poor sorting of the framework components, point to textural immaturity of the studied deposits. Moreover, the most frequent types of grain contacts show only a very low effect of compaction. Effects of other more advanced diagenetic processes (dissolution, cementation or recrystallization) were not observed in the examined samples. The analysed deposits are petrographically sub-mature, which is marked by the high content of lithic clasts and a relatively high amount of feldspars (up to $\sim 10 \%$ ).

The description of the studied sandy deposits is supplemented by sieve analysis of two sand samples, B1(s) and $\mathrm{B} 3(\mathrm{~s})$. According to the mean grain-size (Mz: 1.34 and 2.33), the sands can be classified as medium- and fine-grained. The deposits are poorly sorted, which is expressed by the standard deviation values ( $\delta: 1.6$ and 1.27). The skewness values (Sk: 0.36 and 0.12 ) point to high and very high participation of finer grain-size classes. The results allow concluding that the deposits were transported in a high-energy sedimentary environment and/or the transport distance was relatively short.

\section{TUFFITE PETROGRAPHY}

The rock is composed of pyroclastic and siliciclastic material (Fig. 7). It is poorly sorted, and grains of different sizes, ranging from clay to sand, are randomly mixed forming a homogeneous texture. The main component is mostly unaltered volcanic glass (Table 3), which is transparent and isotropic. Slight alteration to clay minerals is rarely observed. The coarser sandand silt-sized grains frequently exhibit a characteristic $Y$-, $X$-shaped and curved morphology and are not compacted, although their external surface is commonly corroded (Fig. 8). They represent very well-preserved glass shards (Figs. 7C-E and 8). Some larger vitroclasts exhibit a vesicular texture (Figs. $7 \mathrm{~F}$ and $8 \mathrm{~B})$. The thickness of the glass shards and the curvature of their external surfaces indicate that they originated from the fragmentation of strongly vesicular material prior to eruption. Besides vitroclasts, crystaloclasts also occur, although in small quantities. They are quartz and alkali feldspar grains that bear no traces of abrasion. Quartz crystaloclasts are often elongated, very angular and sometimes show thermal cracks and corrosion embayments. These features are typical for quartz in volcanic rocks. Alkali feldspar crystaloclasts are less common than quartz. They are sub- to euhedral, have a tabular, elongated habit and sometimes show simple twinning. Elemental composition of glass shards studied with EMP in 25 points in two thin sections is invariable. They contain on average $76.4 \%$ of $\mathrm{SiO}_{2}$ ( $\mathrm{sd}=0.49 \%$ ), $11.9 \%$ of $\mathrm{Al}_{2} \mathrm{O}_{3}$ ( $\mathrm{sd}=0.08 \%$ ), $2.8 \%$ of $\mathrm{K}_{2} \mathrm{O}$ ( $\mathrm{sd}=0.50 \%$ ), $2.7 \%$ of $\mathrm{Na}_{2} \mathrm{O}$ ( $\left.\mathrm{sd}=0.29 \%\right), 1.0 \%$ of $\mathrm{FeO}$ ( $\mathrm{sd}=$ $0.05 \%), 0.6 \%$ of $\mathrm{CaO}$ ( $\mathrm{sd}=0.03 \%$ ) and insignificant amounts (on average $<0.1 \%$ ) of $\mathrm{MgO}, \mathrm{MnO}, \mathrm{BaO}, \mathrm{TiO}_{2}, \mathrm{ZrO}_{2}, \mathrm{P}_{2} \mathrm{O}_{5}, \mathrm{~F}$ and $\mathrm{Cl}$. Totals are on average $95.8 \%(\mathrm{sd}=0.66 \%)$ with the remaining part being probably chiefly water.

The siliciclastic material comprises mono- and polycrystalline quartz, often with wavy extinction, alkali feldspars, plagioclase, muscovite and clay minerals. Mud clasts composed of clay minerals and silt-sized quartz are also present as lithic clasts. They represent sediments that probably experienced intrabasinal redeposition, because they show an internal chaotic arrangement of the platy minerals indicating that they did not undergo significant mechanical compaction. Silt-sized zircon grains were also found, but they are too small to determine whether they are genetically related to the pyroclastic or siliciclastic material under the polarizing microscope. The siliciclastic grains are mixed with pyroclastic material and have similar grain sizes and sorting. However, unlike the pyroclasts, they have more isometric shapes, exhibit moderate rounding, and apparently experienced some mechanical reworking during transport.

\section{U-Pb GEOCHRONOLOGY}

The main goal of the $\mathrm{U}-\mathrm{Pb}$ analysis was to establish the age of volcanic ash deposition. From 62 age determinations for 50 crystals, one was excluded due to $>10 \% 1 \sigma$ uncertainty of the ${ }^{206} \mathrm{~Pb} /{ }^{238} \mathrm{U}$ age. A total of 13 grains from 49 dated yield Neogene ages ( 27\%) (Table 4 and Fig. 9). Other crystals have signifi- 

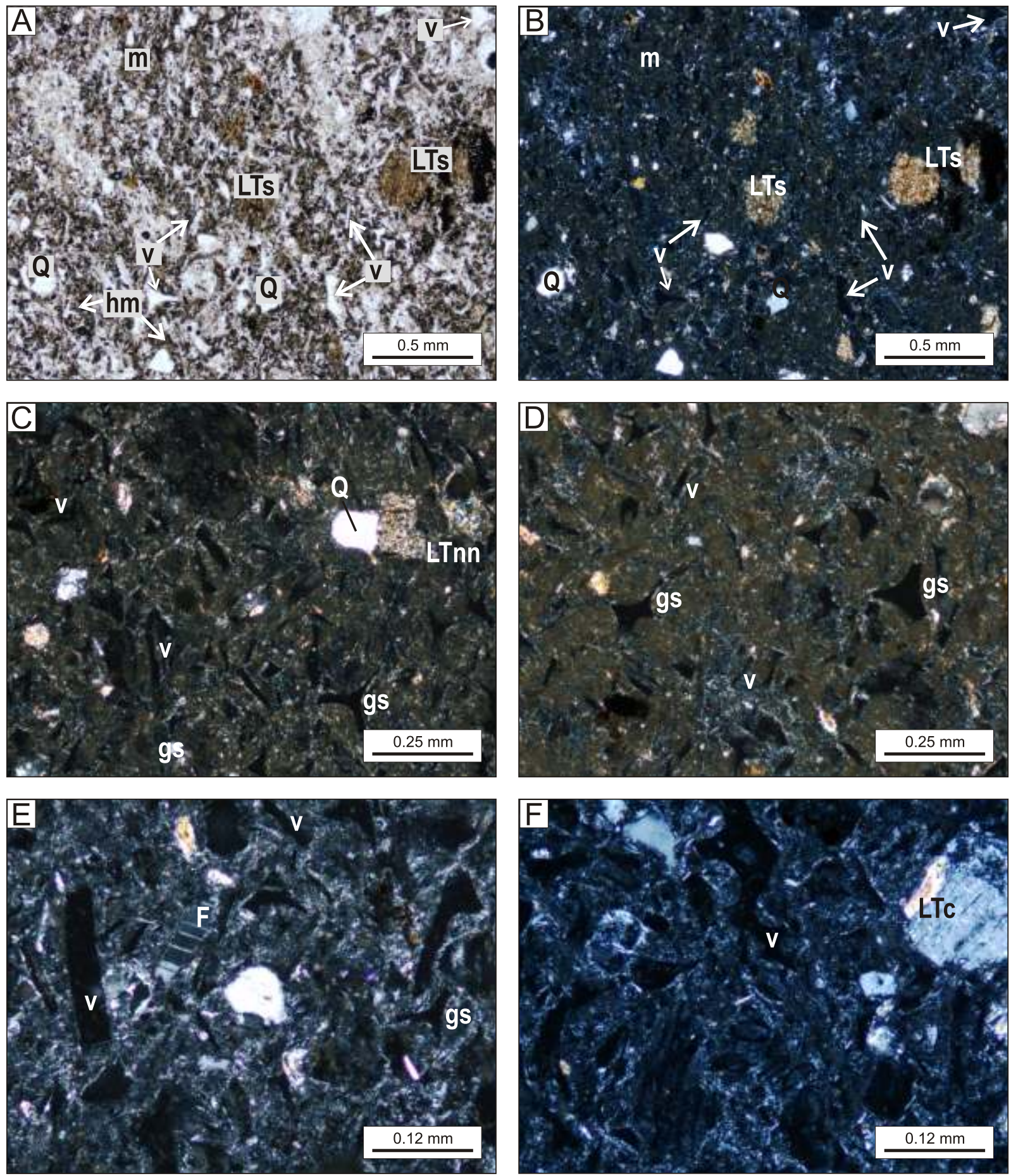

Fig. 7. Photomicrographs showing the texture and composition of the studied tuffaceous deposits

Pyroclastic and siliciclastic grains are embedded in a matrix composed of fine glass and clay minerals; vitroclasts exhibit variable morphology; some are very well-preserved glass shards (gs) with a vesicular texture; $F$ - feldspars; $h m$ - heavy minerals, LTc lithic clasts of crystalline rocks, LTnn - non-recognizable lithic clasts, LTs - lithic clasts of sedimentary rocks, $m-$ matrix, Q quartz, $v$ - vitroclasts, $A$ and $B$ is the same area observed under plane polarized and cross polarized light, respectively; B-F crossed polarized light

cantly older U-Pb ages, which vary from 255 to $873 \mathrm{Ma}$, with 2 crystals yielding ages $>1 \mathrm{Ga}$. Among these scattered results, a group of 19 crystals ( $39 \%$ of all grains) with ages between 255 $\pm 2 \mathrm{Ma}$ and $378 \pm 13 \mathrm{Ma}$ can be distinguished. These results are not discussed further in this paper.
In 13 Neogene crystals, a total of 19 LA-ICP-MS analyses were performed, at a maximum of two per zircon grain. In 6 cases, additional analyses were conducted on the ablating crystal edge, whereas the centre of the crystal was the target for all 13 grains. The crystals yield ${ }^{206} \mathrm{~Pb} /{ }^{238} \mathrm{U}$ ages between 11.43 $\pm 0.35 \mathrm{Ma}$ and $13.47 \pm 0.49 \mathrm{Ma}$. Analytical uncertainties $(1 \sigma)$ on 

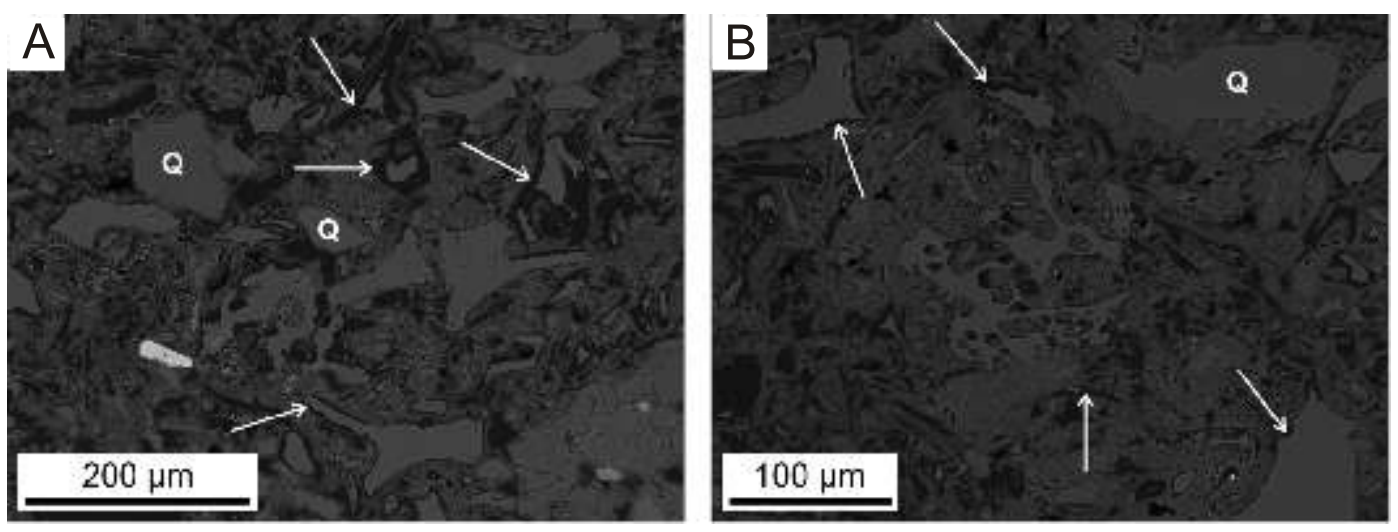

Fig. 8. BSE images of tuffite

Most of the framework grains are glass shards exhibiting different degrees of diagenetic corrosion on their external surfaces (arrows indicating black areas are filled with epoxy resin); quartz grains $(Q)$ are characterized by a similar BSE intensity to that of volcanic glass, but they do not exhibit diagenetic corrosion; note vesicular texture of some vitroclasts, especially in the centre of $B$
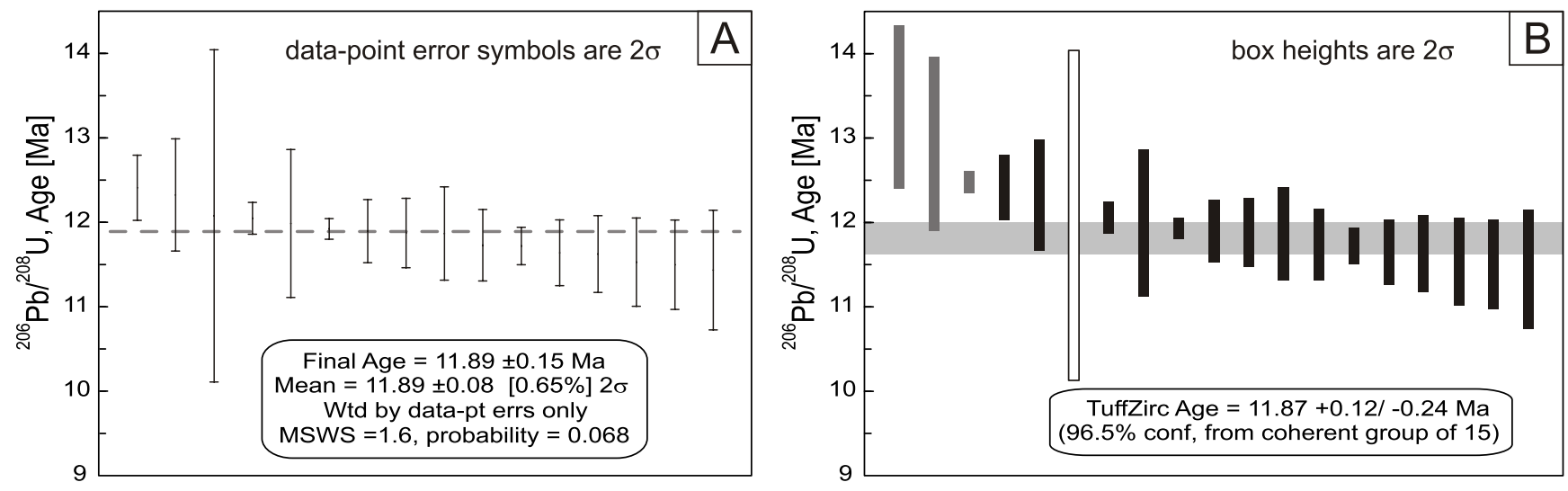

Fig. 9A - diagram of individual ${ }^{206} \mathrm{~Pb} /{ }^{208} \mathrm{U}$ ages obtained in zircon grains from the Bystry tuffite layer corresponding to the calculated weighted mean age (dashed line); B - TuffZirc algorithm diagram; light grey band shows the inferred age and uncertainty of syngenetic zircons; black boxes are error bars for arguably syngenetic zircons, grey boxes are error bars for zircons likely to be xenocrystic or to have experienced a longer magma-residence time; white box indicates analysis ignored due to an anomalously high error

individual age determinations are between 0.5 to $4 \%, \sim 2 \%$ on the average. The difference in the U-Pb ages between the crystal's edge and core is $<0.25 \mathrm{Ma}$ in four, and $<0.5 \mathrm{Ma}$ in two grains. These differences are within or just beyond the $1 \sigma$ level uncertainty of the age determination.

The final age of the volcanic ash deposition was determined using two different approaches. First, the age was calculated based on the weighted mean diagram of 16 youngest age determinations ( $2 \sigma$ level uncertainty) using the routines in Isoplot (Ludwig, 2008). This approach yielded an age of the tuffite layer at $11.89 \pm 0.15 \mathrm{Ma}$ (Fig. 9A). Three excluded ages from 2 grains were assumed to come from xenocrysts. The youngest ages were not trimmed from the dataset for the age calculation because of the small difference in the core and edge age determination and thus most probably small $\mathrm{Pb}$ loss.

The second approach was based on the TuffZirc algorithm (Ludwig and Mundil, 2002) also provided in Isoplot. This algorithm was specifically designed to avoid bias in the manual data set trimming during age calculation. For this approach, all 19 age determinations were used. The algorithm pointed to 15 ages as being a coherent group, with the final age of the volca- nic ash deposition at $11.87+0.12 /-0.24 \mathrm{Ma}$ (Fig. 9B). One age was excluded due to the high $2 \sigma$ level uncertainty and 3 ages were excluded as probable xenocrysts or affected by a longer magma-residence time.

\section{DISCUSSION}

The studied tuffite layer constitutes an excellent opportunity for the precise dating of the basin infill. However, the relation of the Bystry Stream succession to the main part of the basin (from Námestovo to Chochołów and Czarny Dunajec villages, Fig. 2A) remains unclear. The studied sedimentary succession is located at the southeastern flank of the Orava Basin, and is separated from the main part of the basin by the Quaternary valley of Bystry and Cichy streams (Fig. 2B; Birkenmajer, 1979). This area was affected by tectonic activity manifested by fractures, faults, and travertine occurrences (Tokarski and Zuchiewicz, 1998; Kukulak, 1999; Struska, 2008), as well as contemporary earthquakes (Baumgart-Kotarba, 2001; Guterch et al., 2005). This activity was related to the Orava strike-slip 
$\mathrm{U}-\mathrm{Pb}$ results and apparent ages and errors for Neogene zircon grains from the Bystry tuffite layer

\begin{tabular}{|c|c|c|c|c|c|c|c|c|c|}
\hline \multirow{2}{*}{ Analysis } & Concentrations & $\begin{array}{c}\text { Isotope } \\
\text { ratios }\end{array}$ & \multicolumn{7}{|c|}{ Apparent ages [Ma] } \\
\cline { 2 - 11 } & $U[\mathrm{ppm}]$ & $\mathrm{U} / \mathrm{Th}$ & ${ }^{207} \mathrm{~Pb} /{ }^{235} \mathrm{U}$ & $1 \sigma[\%]$ & ${ }^{206} \mathrm{~Pb} /{ }^{238} \mathrm{U}$ & $1 \sigma[\%]$ & $R h 0^{206} \mathrm{~Pb} /{ }^{238} \mathrm{U}$ & $1 \sigma$ \\
\hline 1B-2 & 1155 & 0.8 & 0.01239 & 1.7 & 0.00194 & 0.5 & 0.30 & 12.48 & 0.06 \\
\hline 1B-3 & 917 & 1.7 & 0.01244 & 3.4 & 0.00193 & 1.6 & 0.46 & 12.41 & 0.19 \\
\hline 1B-5 & 648 & 1.0 & 0.01114 & 2.9 & 0.00185 & 1.6 & 0.54 & 11.90 & 0.19 \\
\hline 1B-10 & 285 & 1.5 & 0.00988 & 6.2 & 0.00178 & 3.1 & 0.50 & 11.43 & 0.35 \\
\hline 1B-12C & 531 & 1.1 & 0.01074 & 2.8 & 0.00180 & 2.0 & 0.71 & 11.62 & 0.23 \\
\hline 1B-12R & 446 & 1.2 & 0.01016 & 2.3 & 0.00184 & 1.7 & 0.75 & 11.87 & 0.21 \\
\hline 1B-16C & 4222 & 2.5 & 0.01370 & 3.2 & 0.00185 & 0.5 & 0.16 & 11.92 & 0.06 \\
\hline 1B-16R & 1134 & 1.1 & 0.01131 & 3.1 & 0.00182 & 0.9 & 0.31 & 11.72 & 0.11 \\
\hline 1B-18C & 10011 & 2.6 & 0.01961 & 14.3 & 0.00201 & 4.0 & 0.28 & 12.93 & 0.52 \\
\hline 1B-18R & 1147 & 1.6 & 0.01357 & 4.8 & 0.00208 & 3.6 & 0.77 & 13.37 & 0.49 \\
\hline 1B-26C & 667 & 2.7 & 0.01265 & 17.9 & 0.00179 & 2.3 & 0.13 & 11.53 & 0.26 \\
\hline 1B-26R & 955 & 1.2 & 0.01119 & 2.1 & 0.00181 & 1.7 & 0.80 & 11.64 & 0.19 \\
\hline 1B-27 & 1200 & 1.1 & 0.01173 & 2.5 & 0.00182 & 1.8 & 0.73 & 11.73 & 0.21 \\
\hline 1B-29R & 909 & 2.1 & 0.01089 & 3.0 & 0.00179 & 2.3 & 0.78 & 11.50 & 0.26 \\
\hline 1B-29C & 7233 & 3.4 & 0.01250 & 4.1 & 0.00186 & 3.7 & 0.89 & 11.99 & 0.44 \\
\hline 1B-35 & 785 & 1.3 & 0.01171 & 3.8 & 0.00191 & 2.7 & 0.70 & 12.32 & 0.33 \\
\hline 1B-43C & 9427 & 1.8 & 0.01514 & 12.6 & 0.00188 & 8.2 & 0.65 & 12.08 & 0.98 \\
\hline 1B-43R & 1887 & 1.7 & 0.01233 & 2.0 & 0.00187 & 0.8 & 0.40 & 12.05 & 0.09 \\
\hline 1B-50 & 1822 & 3.1 & 0.01333 & 12.5 & 0.00184 & 2.3 & 0.19 & 11.87 & 0.28 \\
\hline
\end{tabular}

fault system constituting the eastern boundary of the main part of the basin (Bac-Moszaszwili, 1993; Baumgart-Kotarba, 1996; Kukulak, 1999). This suggests that the study area is located close to or within the Orava Fault Zone. Thus, it is important to notice that it could have been developed to some extent differently from the main part of the basin.

Considering a lithostratigraphic division based on gastropod shells (Woźny, 1976; Watycha, 1976), the Neogene of the Bystry Stream was assigned to the Koniówka Beds that crop out near Koniówka village. The sedimentary succession of the Bystry Stream was considered by many authors to be a part of the Domański Wierch large alluvial fan (Birkenmajer, 1954; Sikora and Wieser, 1974), as suggested by the common presence of several metre-thick conglomerates.

Additionally, the Neogene of the Domański Wierch Hill was drilled (Urbaniak, 1960; the borehole was 228 m deep), providing data for palaecological and palynological studies. The age deduced from flora remnants is considered to be Middle Miocene (Łańcucka-Środoniowa, 1965), Pliocene-Pleistocene (Oszast, 1970), or Pliocene (Zastawniak, 1972; Oszast, 1973). Flora remnants of the Bystry Stream succession investigated by Worobiec (1994) revealed a relatively poor assemblage of plant taxa; however, all species found there occur also within the Domański Wierch Hill succession. According to Worobiec (1994), no conclusions can be drawn on this basis about the stratigraphic relation between these two sequences.

Assuming the Pliocene-Pleistocene age of the Domański Wierch Hill sequence, supported by most authors, and the Sarmatian age of the tuffite within the Bystry Stream succession, the latter appears to be a much lower part of the basin sequence. The contact between the tuffite and overlying conglomerates is very likely erosional, and the hiatus may be significant. The obtained age of the tuffite may be undoubtedly referred only to the predominantly fine-grained sedimentary sequence beneath the tuffite (Fig. 3). Consequently, the uppermost part of the studied succession, above the erosional surface (Fig. 3), may be a continuation of the much younger Domański Wierch alluvial fan. At this young stage of basin development the erosion of surrounding areas appeared to become much more intensive.

Nevertheless, the obtained age of the tuffite marks the geological time when the main stage of Mesoalpine basement consolidation was already completed. The Central Carpathian Paleogene and the nearby Pieniny Klippen Belt began to be exhumed and eroded, although the terrain relief could have still been moderate (Castelluccio et al., 2016). The obtained age marks also the time when the clastic sedimentation in terrestrial and freshwater environments prevailed.

Moreover, textural immaturity of the sandy facies and mineralogical sub-maturity of their framework composition link the sources of the deposits to areas located relatively close to the basin. Lithology of the gravel clasts is dominated by a group of flysch clasts and, along with the NW-trend of transport direction, points to the CCPB source area. Other lithologies of extrabasinal clasts comprising only a minor part of the gravels may be linked with the PKB.

The U-Pb zircon age of the tuffite layer obtained in this study $(11.87+0.12 /-0.24 \mathrm{Ma}$, Sarmatian in age according to Central Paratethys stratigraphy in Piller et al., 2007) corresponds to the timing of magmatic activity in the Carpathian-Pannonian region. The nearest magmatic rocks of this age, dated at $11.2 \pm 0.2$ to $12.1 \pm 0.3$ Ma by Anczkiewicz and Anczkiewicz (2016) using the same U-Pb method, occur around Szczawnica, some 30-50 $\mathrm{km}$ east of the Bystry Stream. These rocks are calc-alkaline andesites that appear as small intrusions within the Magura Nappe to the north of the PKB. They are probably not the source of eruption that led to the deposition of the examined tuffite, because they are not felsic, as the $\mathrm{SiO}_{2}$ content ranges from 52 to $63 \%$ and quartz phenocrysts are absent (Pin et al., 2004; Trua et al., 2006; Nejbert et al., 2012), whilst the tuffite is rich in glass shards and quartz crystaloclasts. 
The tuffite originated from a fallout deposition of volcanic ash that mixed with the local siliciclastic sediments. The abundance and shape of glass particles suggest that the volcanogenic material was derived from an explosive eruption of viscous and volatile-rich melt. The texture of the pyroclastic material and the preservation of the glass shards suggest that volcanic ash was transported over a relatively short distance and had already cooled during fallout deposition, as it is not thermally welded. The abundance of quartz crystaloclasts and the elemental composition of the glass shards with high silica content $\sim 76 \%$ and significant amounts of $\mathrm{Al}_{2} \mathrm{O}_{3}(\sim 12 \%), \mathrm{K}_{2} \mathrm{O}(\sim 3 \%), \mathrm{Na}_{2} \mathrm{O}(\sim 3 \%)$ and water $(<4 \%)$ confirm that the source was felsic and volatile-rich. The nearest felsic eruptive centres $\sim 12 \mathrm{Ma}$ occur in the Inner Carpathians-Pannonian region (Pécskay et al., 2006), e.g. in central Slovakia $>100 \mathrm{~km}$ south and south-west of the Bystry Stream. They produced an extrusive dacite to rhyolite dome and flow complexes that were accompanied with their explosive counterparts as thick ash-flow and fallout pyroclastic deposits (Pécskay et al., 2006 and references therein). We assume that these eruptive centres are the most probable source of volcanogenic material in the examined tuffite.

Tectonic implications of the obtained age are limited by several different factors that need to be considered. The main tectonic structures involved in the basin development in the investigated area are the $\mathrm{W}-\mathrm{E}$-trending fault between the CCPB and the PKB and the SW-NE-trending sinistral strike-slip Orava Fault (Baugmart-Kotarba, 2001). The latter to the south is most probably connected to the Choč-Prosečné-Krowiarki Fault that bounds the Tatra Massif from the west (Baugmart-Kotarba, 2001; Sperner et al., 2002; Králiková et al., 2014). Tectonic subsidence of the Orava Basin started prior to the tuffite deposition, but it is not possible to estimate the beginning of the process based on the presented results only. The subsidence was already at a stage that allowed accumulation of tens of metres of sediments in the investigated area. On the other hand, the analyzed profile is located within or close to the tectonic zone responsible for the basin development, so it might accumulate sediments in response to even very early stages of fault movement. Taking into account a very high depositional rate associated with strike-slip fault-related basins (e.g., Crowell and Link, 1982; Nilsen and Sylvester, 1995; Wysocka and Świerczewska, 2003) we can consider 13-12 Ma as a probable age of the basin initiation and thus of the tectonic activity of the two above-mentioned faults in the study area.

There are few other tectonic processes that were dated using geo- or thermochronology in the area that can be compared to the results presented herein. The above-mentioned volcanic activity dated at $11.2 \pm 0.2$ to $12.1 \pm 0.3 \mathrm{Ma}$ by Anczkiewicz and Anczkiewicz (2016) was related to post-collisional lithospheric extension in the Western Carpathians and stretching of the overriding plate due to a subduction roll-back effect (Konečný et al., 2002, Kováč et al., 2017). The ascent of magma (associated with the andesites) and tectonic subsidence (associated with deposition in the O-NT Basin) were both preferentially promoted in the tectonically labile and strongly fractured suture zone of the PKB at a similar period of time.

The timing of cooling of the CCPB sediments near the investigated portion of the O-NT Basin was dated using apatite uranium-helium (AHe) and apatite fission track (AFT) thermochronological methods. AHe results from the surface sample ( $\sim 5 \mathrm{~km}$ SE of the Bystry area) points to $13.4 \pm 2.2 \mathrm{Ma}$ as a cooling temperature from $\sim 60-50^{\circ} \mathrm{C}$ (Andreucci et al., 2013). About $10 \mathrm{~km}$ east of the Bystry area, the AFT cooling age (cooling from $\sim 110^{\circ} \mathrm{C}$ ) of the surface CCPB sample close to the PKB is estimated at $12.0 \pm 1.7 \mathrm{Ma}$ (Anczkiewicz et al., 2013). This data suggests that the vicinity of the O-NT Basin was exposed to on- going exhumation process prior to or at the time of basin initiation. However, it is important to note that both results are based on single samples (other samples from the surveys are not located in the vicinity of the Bystry Stream area). Also AFT and $\mathrm{AHe}$ analysis of the flysch-like sediments are problematic due to often low quality of the input material (Andreucci et al., 2013).

More reliable thermochronological data and modelling come from the Tatra Massif. Several independent modern surveys based altogether on $>50$ samples pointed to a time interval from $\sim 22$ to $\sim 10 \mathrm{Ma}$ as the main episode of Neogene exhumation and the related fault activity in the Tatra Massif (Králiková et al., 2014; Anczkiewicz et al., 2015; Śmigielski et al., 2016). At the time of sedimentation of investigated tuffite $(\sim 12 \mathrm{Ma})$, the faults that bound the Tatra Massif from the west (Choč-Prosečné-Krowiarki Fault) and from the east (Ružbachy Fault) acted most probably as strike-slip sinistral faults and sub-Tatra Fault as a reverse structure (Sperner et al., 2002; Králiková et al., 2014; Śmigielski et al., 2016). The $12 \mathrm{Ma}$ age of the tuffite in the Bystry Stream area fits well into these results and the following tectonic interpretation. Both the Tatra Massif exhumation and the subsidence in the Orava area can be related to the processes typical of the evolution of strike-slip fault zones and result from the accommodation of fault displacement during the same time under the same remote stress field (Kim et al., 2004). This might be considered regardless of the potential direct connection between the Choč-Prosečné-Krowiarki and Orava faults.

The question remains if the Tatra Massif exhumation and following development of the O-NT Basin records propagation of the same major strike-slip fault zone from the SW to the NE. Further development of the O-NT Basin after $\sim 12$ Ma was most probably influenced by the changes in the stress field and extrusion of the Western Carpathian crustal wedge toward the NE (Kováč et al., 2017). Without another precise dating, preferably either from the top of the O-NT Basin profile or from the bottom of the alluvial fan, it is not possible to estimate the deposition rate or bring new conclusions to the hypothesis on the further evolution of the O-NT Basin and surrounding areas (Králiková et al., 2014; Tokarski et al., 2016).

\section{CONCLUSIONS}

- The sedimentation of the Bystry Stream succession took place in terrestrial settings, predominantly on floodplains and in rivers, in the vicinity of a hilly area (mostly CCPB, but also PKB) supplying the basin with eroded material.

- The change of sedimentary environments recorded more prominent terrain morphology within the younger deposits, inferred from the oncoming of a large alluvial fan. This may indicate a change in the structural framework of the basin of uncertain age. Assuming the continuity of the topmost part of the studied sequence with the Domański Wierch Cone strata, this could have happened during the Late Miocene-Pliocene.

- The age of the tuffite layer within the Bystry Stream succession was determined at $11.87+0.12 /-0.24 \mathrm{Ma}$. The obtained Sarmatian age of the basal part of the sedimentary infill marks the approximate onset of sedimentation within the O-NT Basin and activity of the Orava Fault in the investigated area.

- The source of volcanogenic material in the tuffite was probably volcanic activity in the Inner Carpathians-Pannonian region, where effusive and volcanoclastic silica-rich rocks were being produced by extrusive and explosive activity $\sim 12 \mathrm{Ma}$. The material was extruded by an explosive eruption and transferred $>100 \mathrm{~km}$ to the north and north-east via aeolian transport. 
- The coincidence of magmatic activity and strong tectonic subsidence $\sim 12 \mathrm{Ma}$ along the PKB in the Polish-Slovakian cross-border area, which represents a tectonically active and strongly fractured suture zone, suggests that both processes could have been induced in a similar tectonic setting

- Recorded timing of the tectonic activity in the O-NT Basin at $\sim 12 \mathrm{Ma}$ fits well into the model of exhumation of the Tatra Massif, constrained by the thermochronological and tectonic data. Subsidence in the O-NT Basin and exhumation in the Tatra Massif can be related to the processes typical of the evolution of areas along active strike-slip fault zones that can occur at the same time under the same remote stress field.
Acknowledgements. Cordial thanks are offered to the reviewers, Prof. M. Kováč (Comenius University in Bratistava) and Prof. A. Świerczewska (AGH University of Science and Technology, Cracow), whose constructive remarks have improved and enriched this paper. M. Pecha from the Arizona LaserChron Center is thanked for $\mathrm{U}-\mathrm{Pb}$ laser analysis. P. Jokubauskas from the Faculty of Geology, University of Warsaw, is acknowledged for conducting EMP analyses. The study was financed by the National Science Centre (NCN) grant No. 011/01/B/ST10/07591.

\section{REFERENCES}

Anczkiewicz, A.A., Anczkiewicz, R., 2016. U-Pb zircon geochronology and anomalous $\mathrm{Sr}-\mathrm{Nd}-\mathrm{Hf}$ isotope systematics of late orogenic andesites: Pieniny Klippen Belt, Western Carpathians, South Poland. Chemical Geology, 427: 1-16.

Anczkiewicz, A.A., Zattin, M., Środoń, J., 2005. Cenozoic uplift of the Tatras and Podhale basin from the perspective of the apatite fission track analyses. Mineralogical Society of Poland - Special Papers, 25: 261-264.

Anczkiewicz, A.A., Środoń, J., Zattin, M., 2013. Thermal history of the Podhale Basin in the internal Western Carpathians from the perspective of apatite fission track analyses. Geologica Carpathica, 64: 141-151

Anczkiewicz, A.A., Danišík, M., Środoń, J., 2015. Multiple low-temperature thermochronology constraints on exhumation of the Tatra Mountains: new implication for the complex evolution of the Western Carpathians in the Cenozoic. Tectonics, $\mathbf{3 4}$ 2296-2317.

Andreucci, B., Castelluccio, A., Jankowski, L., Mazzoli, S., Szaniawski, R., Zattin, M., 2013. Burial and exhumation history of the Polish Outer Carpathians: discriminating the role of thrusting and post-thrusting extension. Tectonophysics, 608: 866-883.

Bac-Moszaszwili, M., 1993. Structure of the western termination of the Tatra massif (in Polish with English summary). Annales Societatis Geologorum Poloniae, 63: 167-193.

Baumgart-Kotarba, M., 1996. On origin and age of the Orava Basin, West Carpathians. Studia Geomorphologica Carpatho-Balcanica, 30: 101-116.

Baumgart-Kotarba, M., 2001. Continuous tectonic evolution of the Orava basin from Late Badenian to the present-day. Geologica Carpathica, 52: 103-110.

Baumgart-Kotarba, M., Marcak, H., Márton, E., 2004. Rotation along the transverse transforming Orava strike-slip fault: based on geomorphological, geophysical and paleomagnertic data (Western Carpathians). Geologica Carpathica, 55: 219-226.

Beleš, F., 1974. Occurrence of bentonite in the Orava river basin (in Slovak with English summary). Mineralia Slovaca, 6: 155-157.

Birkenmajer, K., 1954. Geological investigations of Podhale Neogene (Central Carpathians) (in Polish with English summary). Biuletyn Instytutu Geologicznego, 86: 59-79.

Birkenmajer, K., 1978. Neogene to Early Pleistocene subsidence close to the Pieniny Klippen Belt, Polish Carpathians. Studia Geomorphologica Carpatho-Balcanica, 12: 17-28.

Birkenmajer, K., 1979. Przewodnik geologiczny po pienińskim pasie skałkowym (in Polish). Wyd. Geol., Warszawa.

Blair, T.C., McPherson, J.G., 1994. Alluvial fans and their natural distinction from rivers based on morphology, hydraulic processes, sedimentary processes, and facies assemblages. Journal of Sedimentary Research, 64: 450-489.

Bojanowski, M.J., Wysocka, A., Łoziński, M., 2014. Methanogenesis-driven formation of siderite concretions and a fresh-wa- ter limestone induced by swamp development in the Neogene Orava-Nowy Targ basin. Abstracts book of 19th International Sedimentological Congress, 18-22.08.2014, Geneva, Switzerland, 84

Bojanowski, M.J., Jaroszewicz, E., Košir, A., Łoziński, M., Marynowski, L., Wysocka, A., Derkowski, A., 2016. Root-related rhodochrosite and concretionary siderite formation in oxygen-deficient conditions induced by a ground-water table rise. Sedimentology, 63: 523-551.

Castelluccio, A., Mazzoli, S., Andreucci, B., Jankowski, L., Szaniawski, R., Zattin, M., 2016. Building and exhumation of the Western Carpathians: new constraints from sequentially restored, balanced cross-sections integrated with low-temperature thermochronometry: Western Carpathians tectonic evolution. Tectonics, 35: 2698-2733.

Cieszkowski, M., 1992. Marine Miocene deposits near Nowy Targ, Magura Nappe, Flysch Carpathians (South Poland). Geologica Carpathica, 43: 339-346.

Cieszkowski, M., 1995. Marine Miocene deposits close to Nowy Targ and their importance for determining age of the Orava-Nowy Targ Basin (in Polish with English summary). Kwartalnik AGH Geologia, 21: 153-168.

Crowell, J.C., Link, M.H., 1982. Geologic History of Ridge Basin, Southern California. Society of Economic Paleontologists and Mineralogists, Dallas, TX, Pacific Section, Field Trip Guidebook.

Dott, R.H. Jr., 1964. Wacke, greywacke, and matrix - what approach to immature sandstone classification? Journal of Sedimentary Petrology, 34: 625-632.

Folk, R.L., Andrews, P.B., Lewis, D.W., 1970. Detrital sedimentary rock classification and nomenclature for use in New Zealand. New Zealand Journal of Geology and Geophysics, 13: 937-968.

Garecka, M., 2005. Calcareous nannoplankton from the Podhale Flysch (Oligocene-Miocene, Inner Carpathians, Poland). Studia Geologica Polonica, 124: 353-369.

Gehrels, G.E., Valencia, V., Pullen, A., 2006. Detrital zircon geochronology by Laser-Ablation Multicollector ICPMS at the Arizona LaserChron Center. Paleontology Society Papers, 11: $1-10$.

Gehrels, G.E., Valencia, V., Ruiz, J., 2008. Enhanced precision, accuracy, efficiency, and spatial resolution of U-Pb ages by laser ablation-multicollector-inductively coupled plasma-mass spectrometry. Geochemistry, Geophysics, Geosystems, 9: 1-13.

Golonka, J., Aleksandrowski, P., Aubrecht, M., Chowaniec, J., Chrustek, M., Cieszkowski, M., Florek, R., Gawęda, A., Jarosiński, M., Kępińska, B., Krobicki, M., Lefeld, J., Lewandowski, M., Marko, F., Michalik, M., Oszczypko, N., Picha, F., Potfaj, M., Słaby, E., Ślączka, A., Stefaniuk, M., Uchman, A., elaźniewicz, A., 2005. Orava Deep Drilling Project and the Post Paleogene tectonics of the Carpathians. Annales Societatis Geologorum Poloniae, 75: 211-248. 
Golonka, J., Picha, F. eds., 2006. The Carpathians and their foreland: geology and hydrocarbon Resources. AAPG Memoir, 84.

Guterch, B., Lewandowska-Marciniak, H., Niewiadomski, J., 2005. Earthquakes recorded in Poland along the Pieniny Klippen Belt, Western Carpathians. Acta Geophysica Polonica, 53: 27-45.

Jankj, J., Pospíšil, L., Vass, D., 1984. Contribution of remote sensing to the knowledge of West Carapathians structure (in Slovak with English summary). Mineralia Slovaca, 16: 121-137.

Kaczmarek, A., Oszczypko-Clowes, M., Cieszkowski, M., 2016. Early Miocene age of Stare Bystre Formation (Magura Nappe, Outer Carpathians, Poland) indicated by the calcareous nannoplankton. Geological Quarterly, 60 (2): 341-354.

Kim, Y.S., Peacock, D.C., Sanderson, D.J., 2004. Fault damage zones. Journal of Structural Geology, 26: 503-517.

Kołcon, I., Wagner, M., 1991. Brown coal from Neogene sediments of the Orawa-Nowy Targ Basin - petrological study (in Polish with English summary). Geological Quarterly, 35 (3): 305-322.

Konečný, V., Kováč, M., Lexa, J., Šefara, J., 2002. Neogene evolution of the Carpatho-Pannonian region: an interplay of subduction and back-arc diapiric uptake in the mantle. EGU Stephan Mueller Special Publication Series, 1: 105-123.

Kováč, P., Hok, J., 1993. The Central Slovak Fault System: field evidence of a strike-slip. Geologica Carpathica, 44: 155-160.

Kováč, M., Nagymarosy, A., Oszczypko, N., Ślączka, A., Csontos, L., Marunteanu, M., Maenco, L., Márton E., 1998. Palinspastic reconstruction of the Carpathian-Pannonian region during the Miocene. In: Geodynamic Development of the Western Carpathians (ed. M. Rakús): 189-217. Geological Survey of Slovak Republic, Bratislava.

Kováč, M., Márton, E., Oszczypko, N., Vojtko, R., Hók, J., Králiková, S., Plašienka, D., Klučiar, T., Hudackova, N., Oszczypko-Clowes, M., 2017. Neogene palaeogeography and basin evolution of the Western Carpathians, Northern Pannonian domain and adjoining areas. Global and Planetary Change, 155.

Králiková, S., Vojtko, R., Sliva, L., Minár, J., Fügenschuh, B. Kováč, M., Hók, J., 2014. Cretaceous-Quaternary tectonic evolution of the Tatra Mts (Western Carpathians): constraints from structural, sedimentary, geomorphological, and fission track data. Geologica Carpathica, 65: 307-326.

Kukulak, J., 1999. Orientation of joints and faults in the SE part of the Orawa Depression (in Polish with English summary). Przegląd Geologiczny, 47: 1021-1026.

Longiaru, S., 1987. Visual comparators for estimating the degree of sorting from plane and thin section. Journal of Sedimentary Petrology, 57: 791-794.

Ludwig, K., 2008. Isoplot 3.6: Berkeley Geochronology Center Special Publication, 4.

Ludwig, K.R., Mundil, R., 2002. Extracting reliable U-Pb ages and errors from complex populations of zircons from Phanerozoic tuffs. Geochimica et Cosmochimica Acta, 66 Supplement, 1 : 463.

Łańcucka-Środoniowa, M., 1965. Palaeobotanical investigations on the Miocene of Southern Poland (in Polish with English summary). Annales de la Société Géologique de Pologne, 33 : 129-148.

Łoziński, M., Wysocka, A., Ludwiniak, M., 2015. Neogene terrestrial sedimentary environments of the Orava-Nowy Targ Basin: a case study of the Oravica River section near Čimhová, Slovakia. Geological Quarterly, 59 (1): 21-34.

Łoziński, M., Ziółkowski, P., Wysocka, A., 2017. Tectono-sedimentary analysis using the anisotropy of magnetic susceptibility: the study of terrestrial and fresh-water Neogene of the Orava Basin. Geologica Carpathica, 68: 479-500.

Miall, A.D., 2000. Principles of Sedimentary Basin Analysis. Springer, Berlin.

Miall, A.D., 2006. The Geology of Fluvial Deposits: Sedimentary Facies, Basin Analysis and Petroleum Geology. Springer, Berlin.

McBride, E.F., 1963. A classification of common sandstones. Journal of Sedimentary Petrology, 34: 664-669.
Nagy, A., Vass, D., Petrik, F., Pereszlényi, M., 1996. Tectogenesis of the Orava Depression in the light of latest biostratigraphic investigations and organic matter alteration studies. Slovak Geological Magazine, 1/96: 49-58.

Nejbert, K., Jurewicz, E., Macdonald, R., 2012. Potassium-rich magmatism in the Western Outer Carpathians: magmagenes is in the transitional zone between the European Plate and Carpathian-Pannonian region. Lithos, 146-147: 34-47.

Nilsen, T.H., Sylvester, A.G., 1995. Strike-slip basins. In: Tectonics of Sedimentary Basins (eds. C.J. Busby and R.V. Ingersoll): 425-457. Blackwell, Cambridge.

Oszast, J., 1970. On the age of the Domański Wierch Cone determined by palynological methods (in Polish with English summary). Kwartalnik Geologiczny, 14 (4): 843-845.

Oszast, J., 1973. The Pliocene profile of Domański Wierch near Czarny Dunajec in the light of palynological investigations (Western Carpathians, Poland). Acta Palaeobotanica, 14: 3-42.

Oszast, J., Stuchlik, L., 1977. The Neogene vegetation of the Podhale (West Carpathians, Poland) (in Polish with English summary). Acta Palaeobotanica, 18: 45-86.

Oszczypko, N., Oszczypko-Clowes, M., Golonka, J., Marko, F., 2005. Oligocene-Lower Miocene sequences of the Pieniny Klippen Belt and adjacent Magura Nappe between Jarabina and the Poprad River (East Slovakia and South Poland): their tectonic position and palaeogeographic implications. Geological Quarterly, 49 (4): 379-402.

Pettijohn, F.J., Potter, P.E., Siever, R., 1972. Sand and Sandstones. Springer, New York.

Pécskay, Z., Lexa, J., Szakács, A., Seghedi, I., Balogh, K., Konečny, V., Zelenka, T., Kovacs, M., Póka, T., Fülöp, A., Márton, E., Panaiotu, C., Cvetković, V., 2006. Geochronology of Neogene magmatism in the Carpathian arc and intra-Carpathian area. Geologica Carpathica, 57: 511-530.

Picard, M.D., 1971. Classification of fine-grained sedimentary rocks. Journal of Sedimentary Petrology, 41: 179-195.

Piller, W.E., Harzhauser, M., Mandic, O., 2007. Miocene Central Paratethys stratigraphy-current status and future directions. Stratigraphy, 4: 151-168.

Pin, C., Bouvier, A., Aleksandrowski, P., 2004. Major trace element and Sr-Nd isotope data on Neogene andesitic rocks from the Pieniny Klippen Belt (southern Poland) and geodynamic inferences. Mineralogical Society of Poland-Special Paper, 24: 323-328.

Pomianowski, P., 2003. Tectonics of the Orava-Nowy Targ Basin results of the combined analysis of the gravity and geoelectrical data (in Polish with English summary). Przegląd Geologiczny, 51: 498-506.

Pospiśil, L., 1990. The present possibilities of identification of shear zones in the area of the West Carpathians (in Slovak with English summary). Mineralia Slovaca, 22: 19-31.

Pouchou, J.L., Pichoir, F., Boivin, D., 1990. XPP procedure applied to quantitative EDS X-ray analysis in the SEM. In: Microbeam Analysis (eds. J.R. Michael and P. Ingram): 120-126. San Francisco Press, San Francisco.

Powers, M.C., 1953. A new roundness scale for sedimentary particles. Journal of Sedimentary Petrology, 23: 117-119.

Raciborski, M., 1892. Zapiski paleobotaniczne. Kosmos, Lwów, 17: 526.

Roth, Z., Benešová, E., Čechovič, V., Eliáš, M., Hanzlíková, E., Chmelík, F., Matějka, A., Pícha, F., 1963. Vysvetlivky k prehladnej geologickej mape ČSSR 1:200 000, M-34-XX Trstená (in Slovak). Geofond, Bratislava.

Sikora, W., Wieser, T., 1974. Utwory piroklastyczne w utworach neogeńskich śródgórskiej niecki Orawy-Nowego Targu (in Polish). Kwartalnik Geologiczny, 18 (2): 441-443.

Sperner, B., Ratsbacher, L., Nemčok, M., 2002. Interplay between subduction retreat and lateral extrusion: Tectonics of the Western Carpathians. Tectonics, 21: 1051-1075.

Stacey, J.S., Kramers, J.D., 1975. Approximation of terrestrial lead isotope evolution by a two-stage model. Earth and Planetary Science Letters, 26: 207-221. 
Struska, M., 2008. Neogeńsko-czwartorzędowy rozwój strukturalny Kotliny Orawskiej w świetle badań geologicznych, geomorfologicznych oraz teledetekcyjnych (in Polish). Ph.D. thesis, Wydział Geologii, Geofizyki i Ochrony Środowiska, Akademia Górniczo-Hutnicza, Kraków.

Śmigielski, M., Sinclair, H.D., Stuart, F.M., Persano, C., Krzywiec, P., 2016. Exhumation history of the Tatry Mountains, Western Carpathians, constrained by low temperature termochronology. Tectonics, 35: 187-207.

Środoń, J., Clauer, N., Banaś, M., Wójtowicz, A., 2006. K-Ar evidence for a Mesozoic thermal event superimposed on burial diagenesis of the Upper Silesia Coal Basin. Clay Minerals, 41 671-692.

Tokarski, A.K., Zuchiewicz, W., 1998. Fractured clasts in the Domański Wierch series: contribution to structural evolution of the Orava Basin (Carpathians, Poland) during Neogene through Quaternary times (in Polish with English summary). Przegląd Geologiczny, 46: 62-66.

Tokarski, A.K., Świerczewska, A., Zuchiewicz, W., Starek, D., Fodor, L., 2012. Quaternary exhumation of the Carpathians: a record from the Orava-Nowy Targ Intramontane Basin, Western Carpathians (Poland and Slovakia). Geologica Carpathica, 63 : 257-266.

Tokarski, A.K., Márton, E., Świerczewska, A., Fheed, A., Zasadni, J., Kukulak, J., 2016. Neotectonic rotations in the Orava-Nowy Targ Intramontane Basin (Western Carpathians) an integrated palaeomagnetic and fractured clasts study. Tectonophysics, 685: 35-43.

Trua, T., Serri, G., Birkenmajer, K., Pécskay, Z., 2006. Geochemical and $\mathrm{Sr}-\mathrm{Nd}-\mathrm{Pb}$ isotopic compositions of Mts Pieniny dykes and sills (West Carpathians): evidence for melting in the lithospheric mantle. Lithos, 90: 57-76.

Urbaniak, J., 1960. The bore-hole at Domański Wierch, near Czarny Dunajec, Podhale area (in Polish with English summary). Kwartalnik Geologiczny, 4 (3): 787-799.
Watycha, L., 1976. The Neogene of the Orava-Nowy Targ Basin (in Polish with English summary). Kwartalnik Geologiczny, 20 (4): 575-585.

Watycha, L., 1977. Objaśnienia do Szczegółowej mapy geologicznej Polski 1:50,000, arkusz Czarny Dunajec (1048) (in Polish). Polish Geol. Inst., Warsaw.

Westwalewicz-Mogilska, E., 1974. Tuffite in the Neogene molasse of the Domański Wierch alluvial cone. Bulletin of the Polish Academy of Sciences, Earth Sciences, 22: 173-178.

Wetzel, A., Einsele, G., 1991. On the physical weathering of various mudrocks. Bulletin of the International Association of Engineering Geology, 44: 89-100.

Wieser, T., 1985. Teschenite formation and other evidences of magmatic activity in the Polish Flysch Carpathians and their geotectonic and stratigraphic significance. In: Fundamental Researches in the Western Part of the Polish Carpathians. Guide to excursion 1, Geol. Inst. Poland: 23-36.

Williams, H., Turner, F.J., Gilbert, C.M., 1982. Petrography, an Introduction to the Study of Rocks in Thin Sections, 2nd ed. Freeman, W.H. San Francisco, CA.

Worobiec, G., 1994. Upper Miocene fossil plants from the outcrop of Stare Bystre (Western Carpathians, Poland). Acta Palaeobotanica, 34: 83-105.

Woźny, E., 1976. Stratigraphy of the Younger Tertiary in the Orawa-Nowy Targ Basin on the basis of fresh-water and continental macrofaunal (in Polish with English summary). Kwartalnik Geologiczny, 20 (3): 589-595.

Wysocka, A., Świerczewska, A., 2003. Alluvial deposits from the strike-slip fault Lo River Basin (Oligocene/Miocene), Red River Fault Zone, north-western Vietnam. Journal of Asian Earth Sciences, 21: 1097-1112.

Zastawniak, E., 1972. Pliocene leaf flora from Domański Wierch near Czarny Dunajec, Western Carpathians, Poland. Acta Palaeobotanica, 13: 1-73.

Zingg, T., 1935. Beiträge zur Schotteranalyse. Schweizerische Mineralogische und Petrographische Mitteilungen, 15: 39-140. 